\title{
Soil Health and Sustainable Agriculture
}

\author{
Monther M. Tahat ${ }^{1}$, Kholoud M. Alananbeh ${ }^{1}\left(\mathbb{D}\right.$, Yahia A. Othman ${ }^{2, *}(\mathbb{1})$ and Daniel I. Leskovar ${ }^{3}$ \\ 1 Department of Plant Protection, The University of Jordan, Amman 11942, Jordan; \\ M.Tahat@ju.edu.jo (M.M.T.); K.Alananbeh@ju.edu.jo (K.M.A.) \\ 2 Department of Horticulture and Crop Science, The University of Jordan, Amman 11942, Jordan \\ 3 Texas A\&M AgriLife Research and Extension Center, Texas A\&M University, Uvalde, TX 78801, USA; \\ d-leskovar@tamu.edu \\ * Correspondence: ya.othman@ju.edu.jo
}

Received: 1 May 2020; Accepted: 10 June 2020; Published: 15 June 2020

\begin{abstract}
A healthy soil acts as a dynamic living system that delivers multiple ecosystem services, such as sustaining water quality and plant productivity, controlling soil nutrient recycling decomposition, and removing greenhouse gases from the atmosphere. Soil health is closely associated with sustainable agriculture, because soil microorganism diversity and activity are the main components of soil health. Agricultural sustainability is defined as the ability of a crop production system to continuously produce food without environmental degradation. Arbuscular mycorrhizal fungi (AMF), cyanobacteria, and beneficial nematodes enhance water use efficiency and nutrient availability to plants, phytohormones production, soil nutrient cycling, and plant resistance to environmental stresses. Farming practices have shown that organic farming and tillage improve soil health by increasing the abundance, diversity, and activity of microorganisms. Conservation tillage can potentially increase grower's profitability by reducing inputs and labor costs as compared to conventional tillage while organic farming might add extra management costs due to high labor demands for weeding and pest control, and for fertilizer inputs (particularly N-based), which typically have less consistent uniformity and stability than synthetic fertilizers. This review will discuss the external factors controlling the abundance of rhizosphere microbiota and the impact of crop management practices on soil health and their role in sustainable crop production.
\end{abstract}

Keywords: mycorrhizal fungi; cyanobacteria; soil tillage; organic farming; microbes; nematodes; biodiversity

\section{Introduction}

Soil health has been defined by Doran and Zeiss [1] as "the capacity of a soil to function as a vital living system within ecosystem and land use boundaries to sustain plant and animal production, maintain or enhance water and air quality, and promote plant and animal health." Soil health is an intrinsic characteristic of a soil. It is recognized as a list of characteristics that define its health and place it taxonomically. Soil quality, conversely, is an extrinsic characteristic of soils and changes with the desired use of that soil by humans. It may relate to agricultural output and capacity to support wildlife, to protect watershed, or provide recreational outputs.

The rapid projected increase in world population to 8.9 billion people by 2050 will lead to higher demands for agricultural products [2]. High food demands and the shortage of new agricultural land development in the future will require doubling crop yields using sustainable means. Scientists can make a substantial contribution to global sustainability of the agricultural lands by translating scientific knowledge on soil function into practical methodologies that enrich grower's knowledge to evaluate the sustainability of their management practices. Two sustainable agricultural management strategies are targeted to increase soil organic matter and reduce erosion through improvements in plant 
diversity and conservational tillage [3]. Meeting the projected demand for healthy and sustainable food production is a crucial challenge. In fact, increasing crop productivity by mitigating climate change and preserving agroecosystems is one of the significant goals of sustainable agriculture [4]. However, meeting agricultural demand by intensive use of synthetic fertilizer and pesticides has led to land degradation and environmental pollution in several agroecosystems which has had an adverse effect on humans, animals and aquatic ecosystems [5]. For example, a multi-year monoculture farming study on wheat resulted in a reduction of soil health, groundwater purity, and beneficial microorganisms leaving plants vulnerable to pathogen and parasites [6]. Sustainable agriculture has been defined as an alternative integrated approach that could be used to solve fundamental and applied issues related to food production in an ecological way [7]. It integrates biological, physical, chemical and ecological principles to develop new practices that are not harmful to the environment [2]. Moreover, sustainability can potentially help to meet food agricultural needs worldwide [6].

The plant rhizosphere is the narrow zone of soil nearest the root system that can sustain crop production with balanced or reduced levels of agrochemical inputs [8]. Soil health assessment is based on soil quality variables that guarantee sustainability of crop production in agricultural lands [1,9]. Several studies showed that soil biota components such as microbial community, abundance, diversity, activity, and stability are important indicators of soil quality $[1,10]$. Soil biota has a great role in plant residues mineralization to form plant nutrients easily absorbed by the plant for growth and development [11]. Soil biota also accelerates the decomposition rate by producing different enzymes that influence plant nutrients kinetics in the soil [12]. Soil microorganisms (mostly, bacteria and fungi) can transform $\mathrm{N}$ between organic and inorganic forms, which in turn influences plant minerals uptake, composition, and production [13]. Microbial communities contribute to fundamental processes that provide stability and productivity of agroecosystems [14]. For example, it has been shown that populations of soil microorganisms such as arbuscular mycorrhizal fungi (AMF), active bacteria, and beneficial nematode are highly correlated with crop yield, fruit quality, soil water storage, and nutrient cycling, playing key roles in improving plant health and soil fertility $[1,10,15]$. Previous research showed that organic farming and conservational tillage (strip tillage) practices can significantly enhance soil biota in watermelon (Citrullus lanatus) and globe artichoke (Cynara cardunculus) grown in clay-loam soils $[10,16]$. A long-term study (7 years) on vegetables and field crops (tomato, carrot, rice, and French bean) revealed that soil microbial biomass carbon in an organic field was higher than a conventional field [17]. In a three-year watermelon study, conservation tillage (strip tillage) was shown to enhance soil fungi abundance and activity as compared to conventional tillage [10]. While tillage practices did not affect mean total earthworm abundance in conventional farming systems (reduced tillage, 153 worms $\mathrm{m}^{-2}$, mouldboard ploughing $130 \mathrm{~m}^{-2}$ ), mean total earthworm abundance in organic farming was $45 \%$ higher in mouldboard ploughing $\left(430 \mathrm{~m}^{-2}\right)$ than in reduced tillage $\left(297 \mathrm{~m}^{-2}\right)$ organic farming [18].

There is a need for global attention on improving or restoring soil health. Assessment of soil health indicators is expected to enhance our understanding of the factors underlying processes that contribute to sustainable agriculture. This review will discuss research findings on soil health management practices and the role of those practices in sustainable crop production. It is intended to provide a better understanding of soil rhizosphere microbiota and the external factors controlling their abundance and diversity.

\section{Soil Biodiversity and Sustainability}

Soil biodiversity refers to all organisms living in the soil. The Convention on Biological Diversity defined the soil biodiversity as "the variation in soil life, from genes to communities, and the ecological complexes of which they are part, that is from soil micro-habitats to landscapes" [19]. Increasing human populations, global climate change, soil degradation, and loss of productive agricultural lands have been shown to increase the pressure on natural resources and threaten processes that maintain global sustainability. [20]. Soil microorganisms connect roots with soil, recycle nutrients, decompose organic 
matter, and respond quickly to any changes occurring in the soil ecosystem, acting as accurate indicators for specific functions in the soil environment [21]. Microbial community functions and their relation with the soil and plant can establish a sustainable soil ecological environment for supporting crop growth, development, and long term yields. Therefore, an understanding of microbial communities' functions, behavior and communication processes in soil and plants are critical for prevention of unexpected management practices before onset of non-repairable damage in the agroecosystem. In fact, understanding microbial activities will provides consistent diagnostics of sustainable soil health and crops production [9].

Soil biota represents one of the largest reservoirs of biodiversity on earth [22]. Global distribution of soil biodiversity (Figure 1) and soil functions are critical for advancing global sustainability because it incorporates essential components including the habitat for aboveground and underwater biota, climatic factors, water quality, pollution remediation, and food production [23,24]. Soil biota affects ecosystem stability by regulating plant diversity, aboveground net primary production, and species asynchrony [22].

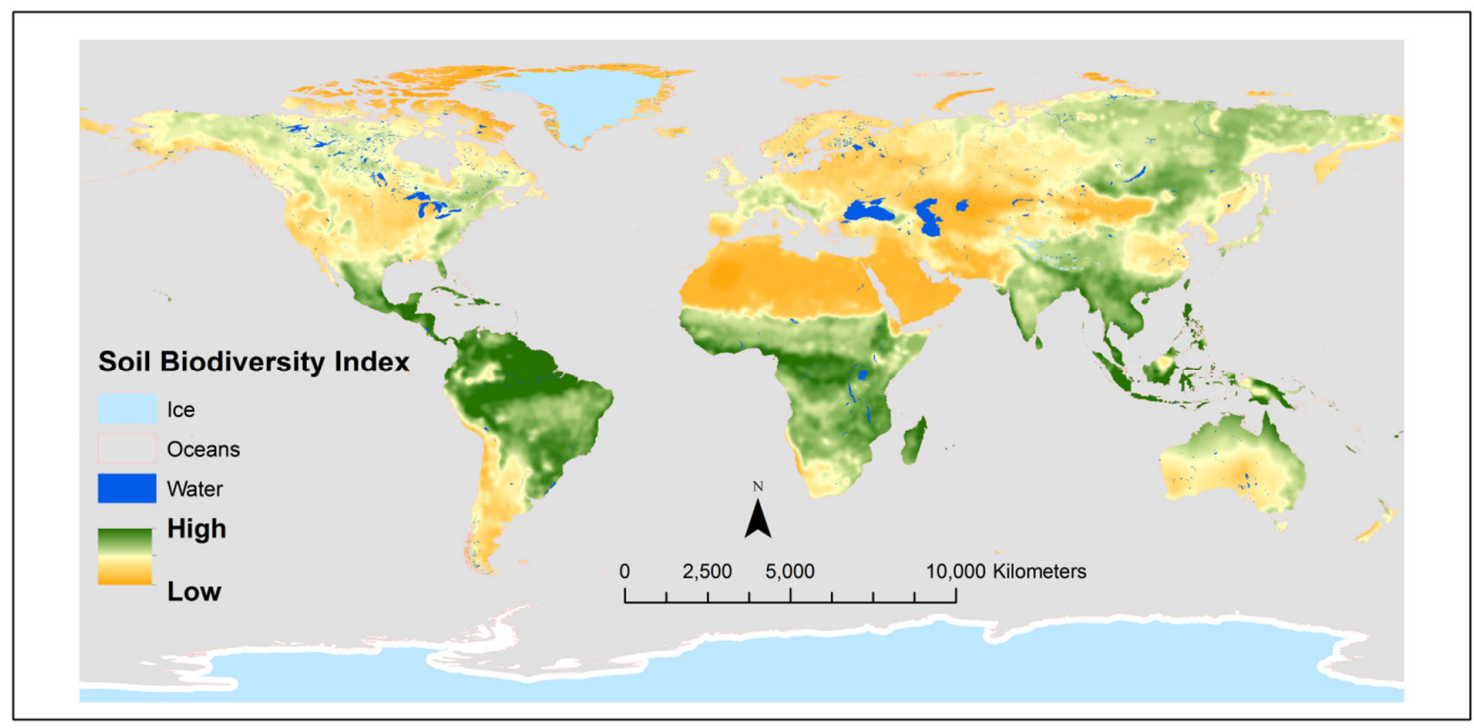

Figure 1. Global distribution of soil biodiversity. To derive this map, two sets of data were used. (1) The distribution of microbial soil carbon developed by Serna-Chavez and colleagues [25]. This dataset was used as a proxy for soil microbial diversity. (2) The distribution of the main groups of soil macrofauna (used as a proxy for soil fauna diversity). "Global Soil Biodiversity Maps" associated to the Global Soil Biodiversity Atlas, developed by the European Soil Data Centre (ESDAC), Joint Research Centre of the European Commission, June 2016 [26]. Permission to reprint this map was obtained from the ESDAC.

Root-associated soil biota promotes ecosystem stability by influencing how plant species response to changes in the environment; for example by improving plant adaptation to extreme stresses (drought, salinity, and temperatures) induced by climate changes [22]. However, recent reports postulated that global soil biodiversity is threatened (Figure 2), especially in areas with high human populations and intensive land use practices [23]. Soil biodiversity stressors included intensive human use, climate change, and loss of aboveground biodiversity, overgrazing, soil organic matter decline, pollution, soil erosion, and land degradation [26]. Therefore, identifying the threats and intervention to soil biodiversity is critical for global agricultural sustainability. 


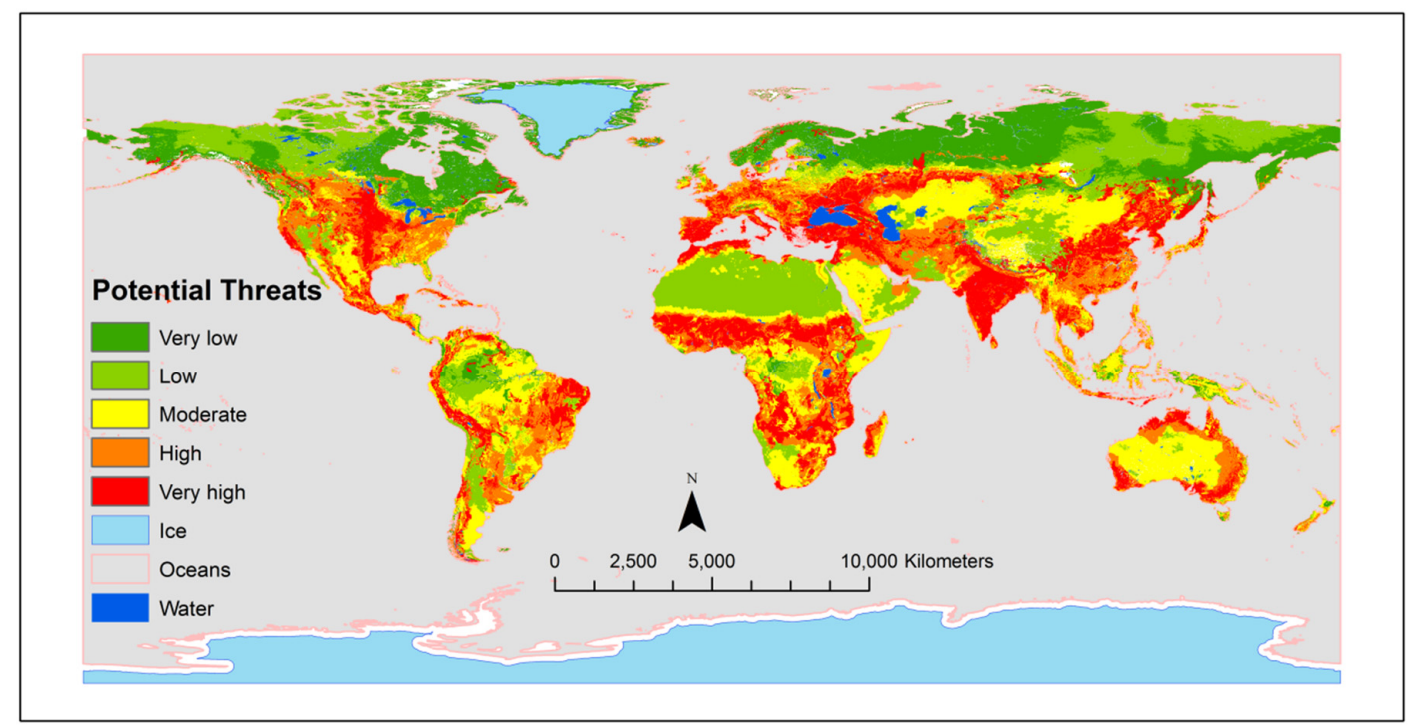

Figure 2. Global potential threats to soil biodiversity. The map shows the potential rather than the actual level of threat to soil organisms. To derive this map, several sets of data were used [26]. "Soil Biodiversity threats map" associated to the Global Soil Biodiversity Atlas, developed by the European Soil Data Centre (ESDAC), Joint Research Centre of the European Commission, June 2016 [26]. Permission to reprint this map was obtained from the ESDAC.

Understanding the role of soil biota in mediating soil processes is important in sustaining crop growth and productivity. Soil functions include collective characteristic and processes, such as decomposition, nutrient cycling, and the regulation of populations [27]. The ecological processes in the soil are nutrient cycling (especially, $\mathrm{N}$ ) and decomposition [24,28]. Both processes are generally driven by soil biota [26]. Nitrogen cycling potential is highly associated with soil species biodiversity rather than species richness. For example, soil decomposer biodiversity losses resulted in slower rates in litter decomposition across biomes and consequently lower nitrogen cycling [28]. An essential agronomical practice to promote soil biota-mediated decomposition and mineralization is the selection of proper organic residue(s) with the inherent susceptibility of residue to physical breakdown and enzymatic hydrolysis [29]. Overall, functional capabilities of microbial communities to nutrient acquisition, mobilization, fixation, recycling, decomposition, degradation, and remediation in the soil connect microbial capabilities with soil health and agricultural sustainability [9].

\section{Soil Health Components for Sustainable Agriculture}

Soil health and soil quality are terms used interchangeably within the scientific literature and some believe that they are synonymous functionally. However, the term soil quality is preferred by the scientists while farmers prefer soil health [30]. Ritz et al. [27] identified and screened 183 biological indicators for monitoring soils. The most common biological indicator candidates were: (1) soil microbial taxa and community structure using terminal restriction fragment length polymorphism techniques, (2) soil microbial community structure and biomass using extracted lipids, in particular phospholipid fatty acids, as signature lipid biomarkers, (3) soil respiration and C cycling from multiple substrate-induced respiration, (4) biochemical processes from multi-enzyme profiling, (5) nematodes, including maturity index (the distribution of nematodes across functional groups), taxa number, and abundance of individual functional groups, (6) microarthropod, (7) on-site visual recording of soil fauna and flora, (8) pitfall traps for ground-dwelling and soil invertebrates, and (9) microbial biomass, the total quantity of life belowground. However, they concluded that further studies are required to determine how these biological indicators are sensitive to variations in management, and how they are associated with soil functions and that can be used to elucidate specific ecological processes. Overall, identifying soil health component is essential for the successful use of national 
and global agricultural monitoring systems (ground truth data), and consequently to the sustainable development of our agricultural systems.

Healthy soil was shown to suppress pathogens, sustain biological activities, decompose organic matter, inactivate toxic materials and recycle nutrient, energy, and water [31]. Karlen et al. [32] defined soil quality as "the capacity of specific kind of soil to function, within natural or managed ecosystem boundaries, to sustain plant and animal productivity, maintain or enhance water and air quality, and support human health and habitation." Further, a broader defining view to soil quality was provided by Bouma et al. [33] as "the intrinsic capacity of a soil to contribute to ecosystem services, including biomass production." The concept of soil quality allows practical applications with regards to targeted ecosystem services [34]. Soil quality is an increasingly popular concept that encompasses soil biological characteristics and functions in close interaction with chemical and physical properties [35]. As previously indicated, the terms "soil quality" and "soil health" are used as synonymous in the literature. However, they may be differentiated in terms of timescale; "soil health" indicates condition of soil in a short period and "soil quality" over a longer period, much analogous to the condition of a human at a particular time (health) and long time period (quality of life) [36]. Soil health and soil quality terms were used as measurements of soil status, and their assessment is aimed to monitor the influence of present, past, and the future of land use on agricultural sustainability [37].

Unsuitable agricultural practices such as soil salinization, acidification, compaction, crusting, nutrient deficiency, reduction in soil biota biodiversity and biomass, water imbalance, and disruption of elemental cycling reduce soil quality [38]. Normally, soil biota are associated with the suppression of pathogenic organisms, nutrient cycling and detoxification of water storage and responds rapidly to soil management practices $[1,39]$. There are strong relationships between soil biota, soil fertility, and plant health [40]. The role of soil biota in the improvement of land productivity and soil fertility through biological processes was recognized as a key strategy towards agricultural sustainability [41].

\subsection{Distribution of Soil Microorganisms}

Soil aggregates provide the physical environment for microorganisms and play key roles in determining the total number of microorganisms [42]. In humic rendzina (heavy loam calcareous soil) soil, the number of bacteria, actinomycetes, and fungi located in aggregates from 1-3 mm was higher than in those of aggregates 5-7 mm [42]. In addition, climate, vegetation, total organic carbon, and $\mathrm{pH}$ may affect the population density of soil microbes [43]. The assessment of environmental and management factors on the diversity and abundance of rhizosphere microbes showed that soil type was an important variable that affected the microbial population [44]. While clay soil indirectly increased bacterial population through the changes in root length and soil chemical composition ( $\mathrm{pH}, \mathrm{P}$ and $\mathrm{K}$ ), fungal biomass was linked with the enhanced above-ground plant yield [44].

The rhizosphere surrounds plant root zone and is composed of three zones; soil, the rhizoplane (root surface), and the root itself, which is inhabited by endophytic microorganisms [45]. The rhizosphere convers at least $2 \mathrm{~mm}$ of the rhizosplane but its effect extends out to $10 \mathrm{~mm}$ [46] and in some cases like the vesicular arbuscular mycorrhizae, it extends beyond the depletion zone at the root surface [47]. The rhizosphere is a complex hot spot of microorganisms [48] fungi, bacteria, nematodes, protozoa, algae, archaea, viruses, and arthropods [49]. The diversity of microorganisms is greater close to the rhizoplane, but it decreases at distant rhizoplane zones. This was explained by the carbon concentration, which has a direct correlation with the distance from the rhizoplane [46]. Moreover, the release of root exudates and organic material is essential for active microbiome development, a term called "rhizosphere effect" [50]. Interestingly, the complex interactions in the rhizosphere showed that all components (roots, soil, and microbes) could be manipulated or engineered to sustain plant growth and development [51]. For example, a better understanding of the rhizosphere root-soil microbe's interactions and their relationships can help to reduce our dependence on chemical fertilizers by using beneficial microbes [52]. 
Studies on habitat-specific functional microbial communities as prominent indicators raise hope for developing regional or agro-climatic, zone-specific microbial inoculants for successful implications in agriculture and environment [9]. The development and efficiency of commercial microbial inoculants such as AMF, biofertilizers, and microbe-based decomposers offer farmers the potential to reduce synthetic farm inputs (fertilizers and pesticides) and stimulate the opportunity of integrated nutrient and pest management practices for sustainable agriculture [9]. However, when adding exogenous beneficial bacteria into agricultural soils, it is important to analyze the cost-benefit and explore the potential reduction in fertilizer inputs. Current investigations introducing Bacillus spp. into clay soils is under way in a sweet onion production system in Texas (Leskovar et al., unpublished).

Soil and microrhizosphere organisms are considered bio-indicators of soil quality due to their sensitivity and response to small changes in abiotic stresses [50] and their effects on plant structure, composition, and productivity [53]. In fact, it has been postulated that plant productivity under different environmental conditions is correlated with below ground diversity [54]. The rhizosphere microorganisms can promote plant growth and protection from pathogen attack by using a range of mechanisms, such as improving plant nutrient use efficiency, production, selective uptake of Fe and $\mathrm{P}[15,55]$, acting as a frontline defense for plant roots against soil-borne pathogens [56], through antibiosis [57], or inducing systemic resistance [58] and parasitism on soil farms [59].

Beneficial rhizosphere microorganisms such as nitrogen-fixing bacteria, mycorrhizal fungi, plant growth promoting rhizobacteria (PGPR), biocontrol microorganisms, mycoparasitic fungi, and protozoa are the most widely studied rhizosphere organisms for their beneficial effects on plants (Figure 3) [50]. Each group plays a vital role in plant health [60]. However, their interaction with plants could be neutral or harmful depending on the plant and environmental conditions [61]. Beneficial microorganisms could improve plant nutrition and stimulate plant growth directly and indirectly [62].

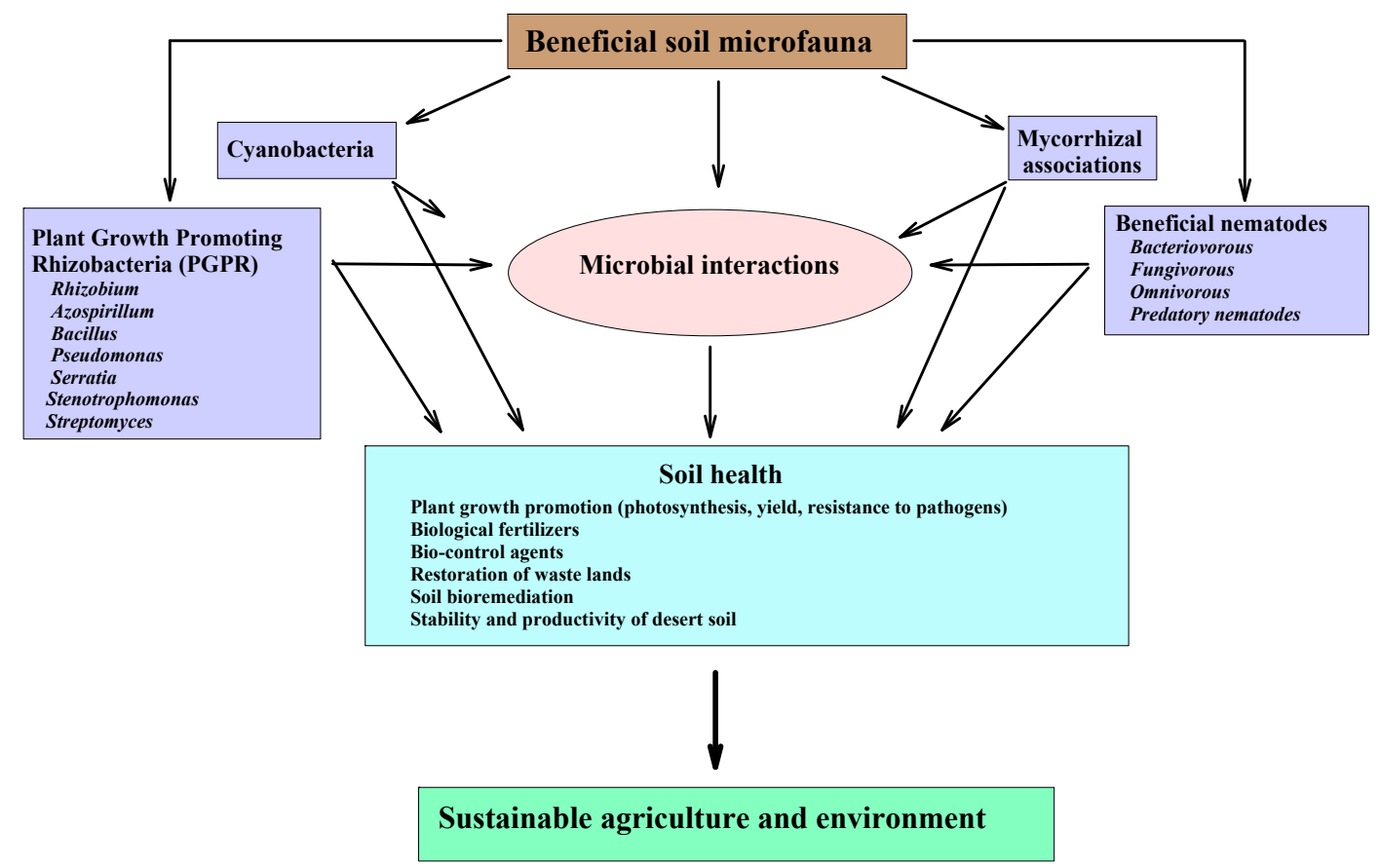

Figure 3. A conceptual theme demonstrating the role of beneficial soil microbes and their interactions for the development of sustainable agriculture and environment (modified from Singh et al. [6] with permission from Elsevier).

Plant growth promoting rhizobacteria represents diverse bacterial taxa [63]. Among them, the most widely successful used plant growth promoting rhizobacteria PGPR on plant inoculations are Azospirillum, Bacillus, Pseudomonas, Rhizobium, Serratia, Stenotrophomonas, and Streptomyces [54-69]. The most investigated and rhizosphere dominant genera of PGPR are Pseudomonas and Bacillus [70]. 
Some fungi have also been reported to be beneficial to plants, i.e., Ampelomyces, Coniothyrium, and Trichoderma [71].

Complex mechanisms are involved in plant growth promotion, development, and protection by PGPR, including biofertilization, phytostimulation, and biocontrol [62].

Biofertilization improves plant nutrient acquisition by providing plants nutrients directly, prompting root growth as well as sustaining beneficial symbiotic relationships [72]. Various microbial taxa have the capacity to access nutrients (P and N) from organic fertilizers and soil residue or to fix atmospheric $\mathrm{N}$, improve water uptake and act as biocontrol agents [73]. The most well-known environmentally friendly biofertilizers for sustainable agriculture are those belonging to Azotobacter, blue green algae, Rhizobium, and Azospirillum [74]. During the plant phytostimulation process, the direct growth enhancement by endogenous plant phytohormones [indole-3-acetic acid (IAA), auxins, cytokinins, and gibberellins] is associated with microorganisms, such as the free-living nitrogen-fixing bacterium (Azospirillum) [75]. However, biocontrol occurs through three strategies, (1) antagonism, in which a direct inhibition occurs for plant pathogens [76], (2) competition for nutrients, oxygen, and trace elements [77], and (3) induced resistance through activation of plant defense mechanisms [78].

\subsubsection{Mycorrhizal Associations}

Mycorrhizal associations have a symbiotic relationship with plant roots [79]. The most common mycorrhizal associations are the AMF, which is found in $80 \%$ of the vascular plants [80]. During evolution, plants developed mycorrhizal associations for nutrient and water uptake [81]. Mycorrhizal associations may also release $\mathrm{C}$ compounds from hyphae to form a niche surrounding the soil, called the mycorhizosphere [82]. AMF have a major role in plant nutrition, enabling absorption of water, $\mathrm{P}, \mathrm{Cu}, \mathrm{Zn}$, and $\mathrm{N}$ [83-85]. AMF also stimulates phytohormones production, such as abscisic acid [86]. In fact, mycorrhizal associations have been shown to play functional roles in mitigating biotic and abiotic stresses in plants $[83,87]$ and favoring soil structure development and stability [85]. Therefore, when evaluating sustainable agricultural systems, it is important to consider the soil-root-AMF interaction as well as the influence of the surrounded soil physical and chemical factors on mycorrhizal associations contributions. It can be concluded that conventional agricultural practices may reduce AMF density while organic low-input system would be viable to increase AMF activity and contribute to the sustainable agricultural development $[83,88]$. Overall, AMF can contribute to sustainable agriculture through improvements in the function of soil rhizospher, leading to positive effects on soil properties and plant agronomic traits, including plant height, grain number, and total yield $[89,90]$.

\subsubsection{Cyanobacteria}

Cyanobacteria are gram-negative prokaryotic photoautotrophic bacteria, abundant in many soils, playing important roles in building-up and maintaining soil fertility [74,91]. They have a significant positive influence on soil health, and plant resistance to abiotic and biotic stresses, such as plant diseases [91,92]. Cyanobacteria are highly adapted to a wide range of extreme environmental conditions, such as temperature $\left(0-70{ }^{\circ} \mathrm{C}\right)$, salinity $\left(\sim 20 \mathrm{dS} \mathrm{m}^{-1}\right), \mathrm{pH}$ (Including high and low $\left.\mathrm{pHs}\right)$, drought, and heavy metals ( $\mathrm{Cd}, \mathrm{Zn}, \mathrm{Mn}, \mathrm{Cu}, \mathrm{Pb}$, and $\mathrm{Co}$ ) [93-98]. The improved plant resistance to desiccation and drought stress can be attributed to the presence of modified vegetative cells (spores and akinetes) in cyanobacteria tissues [98]. Cyanobacteria represent a renewable biomass source of soluble organic matter (non-ribosomal peptides, isoprenoids, ribosomal peptides, alkaloids, and polyketides) which are mineralized by soil microorganisms, which in turn support agricultural crop productivity [99]. In addition, organic matters can act as growth promoters and/or inhibitors for other living organisms [92]. The utilization of indigenous cyanobacteria strains as a bio-fertilizer was shown to significantly improve soil physical, chemical, and biological characteristics, leading to higher yield, especially in saline, dry, and contaminated (heavy metals, $\mathrm{Ni}, \mathrm{Pb}, \mathrm{Cr}$, and Cd) soils [100,101]. 
Cyanobacteria also play a role in chemical transformation of soils by enhancing the bio-availability of plant nutrients, such as P, C, and N [102]. The application of cyanobacteria to poor semi-arid soils can increase $\mathrm{N}$ levels and microorganisms population [103]. Interestingly, cyanobacteria act as bio-control agents against plant pathogens [92]. For example, extracellular products from the cyanobacteria strain Nostco muscorum have shown to have antifungal activity against Rhizoctonia solani in soybean (Glycine max) [104] and white mold of lettuce (Lactuca sativa) caused by Sclerotinia sclerotiorum [105].

\subsubsection{Nematodes}

Evidence is growing that the massive diversity of soil biota contributes significantly to shaping above ground biodiversity, the functioning of terrestrial ecosystem, and ecological responses of those ecosystems to current and future environmental change [24]. Recent studies have shown that the diversity of below ground soil biota communities can affect aboveground plant community components (diversity, productivity, abundance, and adaptation to stress factors) and consequently influence ecosystem stability and resilience [22].

Nematode biodiversity in the agroecosystems is associated with the soil ecological condition. Nematodes have been used in studies of sustainability, as biological indicators of soil quality [106]. Soil nematode communities (structural form and function) have the potential to provide an overview of soil processes because most nematodes are active throughout the year and can provide a measure of the biotic and functional status of soils [107]. Nematodes have been recommended as biological indicators for soil quality assessment because they provide a habitat for biodiversity and are involved in nutrient recycling process [108]. However, comparative studies at very large or trans-national level among climatic zones should be carried out with caution because nematode communities differ among bio-geographical zones and land uses within each bio-geographical zone [108].

Worldwide, the estimate yield loss by parasitic nematode is about $12.3 \%$ [14]. Plant diseases caused by nematodes are difficult to control because of their hidden nature. Nematodes can form disease complexes with microorganisms and increased crop loss [14]. Conversely, beneficial nematodes help plants feeding on bacteria and fungi and release minerals to soil [109]. Those beneficial nematodes have the ability to respond quickly to soil chemical, physical, and biological changes because they are ubiquitous, have diverse feeding behaviors, and a range of life strategies [109,110]. In addition, free-living beneficial nematodes (Discolaimus, Tripyla and Prionchulus) enhance plant growth through the release of $\mathrm{N}$ compounds that are produced as a byproduct of feeding on soil microbes [111].

Nematodes that feed on nematode (bacterivores), as well as algivores and fungivores are useful bio-indicator for soil health $[112,113]$. Predatory nematodes in the orders Mononchida, Dorylaimida, and Diplogasterida feed on the soil microorganisms and plant parasitic nematodes and release minerals into the soil $[114,115]$. Omnivorus nematodes such as Pristionchus are capable of both microbial feeding and predatory feeding on other nematodes. A healthy soil has adequate biological diversity and nutrient cycling [116]. Nutrient cycling and availability depends on various soil trophic microorganisms (bacteriovorous, fungivorous, omnivorous, and predatory nematodes) which play a significant role in the mineralization (release) of nutrients from organic matter. Studies have shown predatory nematodes increasing nutrient mineralization and consequently plant productivity in buffalo grass (Bouteloua gracilis) and perennial ryegrass (Lolium perenne) $[111,115,117]$. Overall, a healthy, well-structured, fertile soil has a massive and wide range of free-living nematodes (specifically, beneficial nematodes) with a good balance between fungal and bacterial feeders as well as having predatory and omnivorous nematodes [118].

\subsubsection{Soil Borne Pathogens}

Soil-borne pathogens cause significant crop loss worldwide. A healthy soil community has a diverse food web that keeps diseases within the control levels through predation, competition, and parasitism [119]. Soil-borne pathogens, such as Rhizoctonia spp., Verticillium spp., Phytophthora spp., Pythium spp., and Fusarium spp. have negative effects on plants growth causing root rot, 
seedling damping off, branch dieback, wilting, and blight diseases [120]. Soil pathogens can survive for many years in the absence of their target host plant by producing persistent structures, such as sclerotia, microsclerotia, chlamydospores, or Oospores [62]. As a result, they are difficult to detect and manage [121]. Sustainable agriculture requires healthy soils to help suppress soil pathogens (Table 1) and effective management of soil-borne inhibitors and pathogens. Thus, by knowing what pathogens are present (identification of causal agents) and the spatial distribution, suitable cultural practices (crop rotation, managing crop residues, and resistance cultivars), soil disinfection, and solarization, biological and chemical control strategies can be followed (Table 1). Soil borne pathogens are critical biological components of soil biodiversity and these microorganisms can be managed to improve soil quality and plant health in sustainable agriculture (Table 1) [122]. Understanding the role of different soil managements practices (Table 1) is key to enhance the agricultural soil health and contribute to long-term crop productivity [122]. Certain crop cultural practices that are designed to manage soil biodiversity in the agroecosystem by suppressing soil borne diseases and improving diversity are shown in Table 1 [123]. 
Table 1. Influence of crop cultural practices on soil borne pathogens.

\begin{tabular}{|c|c|c|c|c|c|}
\hline Cultural Practices & Crops & Hypothesis & Target Pathogens & Responses & References \\
\hline Crop rotation & $\begin{array}{c}\text { Barley (Hordeum vulgare), } \\
\text { rye grass (Lolium perenne) } \\
\text { canola rape seed (Brassica } \\
\text { napus) and potato } \\
\text { (Solanum tuberosum). }\end{array}$ & $\begin{array}{c}\text { Crop rotation (3 years) with } \\
\text { potato will reduce Rhizoctonia } \\
\text { infection. }\end{array}$ & Rhizoctonia spp. & $\begin{array}{l}\text { The disease was reduced } \\
15-50 \% .\end{array}$ & Larkin et al. [124]. \\
\hline Grafting & $\begin{array}{c}\text { Cucumber (Cucumis } \\
\text { sativus). }\end{array}$ & $\begin{array}{l}\text { Grafting cucumber plants } \\
\text { onto different rootstocks (a } \\
\text { non-chemical method) reduce } \\
\text { infection of } \\
\text { root-knot nematodes. }\end{array}$ & Meloidogyne spp. & $\begin{array}{l}\text { Plants grafted onto "Strong } \\
\text { Tosa" rootstock had higher total } \\
\text { number of fruits }(20) \text { and yield } \\
(5.4 \mathrm{~kg}) \text { compared to other } \\
\text { rootstocks or non-grafted plants } \\
\text { in soil infected by } \\
\text { root-knot nematodes. }\end{array}$ & Goreta Ban et al. [125]. \\
\hline $\begin{array}{l}\text { Tillage, crop rotations } \\
\text { and crop residue }\end{array}$ & $\begin{array}{c}\text { Maize (Zea mays) and } \\
\text { wheat (Triticum aestivum). }\end{array}$ & $\begin{array}{l}\text { Technical innovations (zero } \\
\text { tillage, crop rotations, and } \\
\text { residue management) could } \\
\text { improve the productivity and } \\
\text { biophysical sustainability of } \\
\text { sub-tropical highland } \\
\text { cropping systems. }\end{array}$ & $\begin{array}{l}\text { Parasitic nematode } \\
\text { (Pratylenchus thornei) root } \\
\text { rot (Cochliobolus sativus). }\end{array}$ & $\begin{array}{l}\text { A maize-wheat rotation } \\
\text { decreased the incidence of } \\
\text { maize root rot up to } 30 \% \text {. The } \\
\text { incidence of root disease was } \\
\text { lower in wheat than in maize. } \\
\text { In maize, both non-parasitic } \\
\text { and parasitic nematodes } \\
\text { increased under zero tillage. }\end{array}$ & Govaerts et al. [126]. \\
\hline Intercropping system & Faba bean (Vicia faba). & $\begin{array}{l}\text { Disease control is influenced } \\
\text { by intercropping wheat } \\
\text { varieties, suggesting } \\
\text { differences of root exudates as } \\
\text { factors that affected } \\
\text { soil-borne diseases. }\end{array}$ & Fusarium oxysporum. & $\begin{array}{l}\text { Shoot biomass of faba bean } \\
\text { increased by } 13-17 \% \text {, while } \\
\text { disease index decrease faba } \\
\text { bean fusarium wilt by } 48 \% \text {. }\end{array}$ & Dong et al. [127]. \\
\hline $\begin{array}{l}\text { Physical method (steam } \\
\text { soil disinfection) }\end{array}$ & $\begin{array}{l}\text { Tobacco (Nicotiana } \\
\text { tabacum). }\end{array}$ & $\begin{array}{l}\text { Injecting or diffusing hot } \\
\text { water vapor into soil will } \\
\text { reduce Rhizoctonia infection. }\end{array}$ & Rhizoctonia solani. & $\begin{array}{l}\text { Dry heat }\left(70 \text { to } 80^{\circ} \mathrm{C} \text { for } 2 \mathrm{~h}\right) \\
\text { and chemical }(\mathrm{NaCl}) \text { treatments } \\
\text { reduced inoculum levels on } \\
\text { trays up to } 45 \% \text { compared } \\
\text { to controls. }\end{array}$ & Gutierrez et al. [128]. \\
\hline Soil organic residue & Broccoli (Brassica oleracea). & $\begin{array}{l}\text { Broccoli residues mowed and } \\
\text { allowed to dry on the soil } \\
\text { surface for several days } \\
\text { reduce disease incidence. }\end{array}$ & Verticillium dahlia. & $\begin{array}{c}\text { The number of propagules after } \\
\text { two broccoli crops was reduced } \\
\text { by } 94 \% \text {. Disease incidence and } \\
\text { severity were reduced by } 50 \% \\
\text { by broccoli treatments. }\end{array}$ & Xiao et al. [129]. \\
\hline
\end{tabular}


Table 1. Cont.

\begin{tabular}{|c|c|c|c|c|c|}
\hline Cultural Practices & Crops & Hypothesis & Target Pathogens & Responses & References \\
\hline $\begin{array}{l}\text { Physical method (soil } \\
\text { solarization) and } \\
\text { biological control }\end{array}$ & $\begin{array}{c}\text { Tomato } \\
\text { (Lycopersicon esculentum). }\end{array}$ & $\begin{array}{l}\text { Soil solarization in } \\
\text { combination with the fungal } \\
\text { antagonistic Gilocladium } \\
\text { virenes has the potential to } \\
\text { manage southern } \\
\text { blight diseases. }\end{array}$ & Sclerotium rolfsii. & $\begin{array}{l}\text { Solarized soil amended with } \\
\text { Gilocladium virenes reduced the } \\
\text { disease incidence by } 49 \% \text {. }\end{array}$ & Ristaino et al. [130]. \\
\hline Biological control & $\begin{array}{c}\text { Pepper } \\
\text { (Capsicum annuum). }\end{array}$ & $\begin{array}{l}\text { Antagonistic microbes } \\
\text { (Trichoderma harzianum) can } \\
\text { lead to competition and } \\
\text { reduction of disease levels. }\end{array}$ & Phytophthora capsici. & $\begin{array}{l}\text { Leaf inoculation of infected } \\
\text { pepper with Trichoderma } \\
\text { significantly reduced necrosis } \\
\text { legion ( } 28 \mathrm{~mm} \text { ) compared } \\
\text { to control. }\end{array}$ & Sid et al. [131]. \\
\hline $\begin{array}{c}\text { Biological control } \\
\text { (antimicrobial activity of } \\
\text { essential oils) }\end{array}$ & $\begin{array}{l}\text { Lavender (Lavandula } \\
\text { angustifolia), anise } \\
\text { (Pimpinella anisum) } \\
\text { chamomile } \\
\text { (Matricaria recutita), fennel } \\
\text { (Foeniculum vulgare), } \\
\text { geranium (Pelargonium } \\
\text { graveolens), oregano } \\
\text { (Origanum vulgare), } \\
\text { parsley (Petroselinum } \\
\text { crispum) and sage } \\
\text { (Salvia officinalis). }\end{array}$ & $\begin{array}{l}\text { Antimicrobial activity of } \\
\text { several essential oils can } \\
\text { inhibit pathogens infection } \\
\text { under in vitro conditions. }\end{array}$ & $\begin{array}{l}\text { Verticillium fungicola var. } \\
\text { fungicola, Mycogone } \\
\text { perniciosa, and } \\
\text { Cladobotryum sp. }\end{array}$ & $\begin{array}{l}\text { A } 100 \% \text { inhibition of plant } \\
\text { pathogens was achieved by } \\
\text { oregano and geranium oil } \\
\text { extracts at } 0.32 \mu \mathrm{L} \mathrm{mL} L^{-1} \text { of air } \\
\text { after } 4 \text {-day exposure. }\end{array}$ & Tanović et al. [132]. \\
\hline $\begin{array}{l}\text { Bio-fertilizer (Glomus } \\
\text { mosseae), inorganic } \\
\text { Fertilizers }\end{array}$ & Tomato. & $\begin{array}{l}\text { Competition for nutrients will } \\
\text { lead to a reduction of } \\
\text { pathogen population. }\end{array}$ & $\begin{array}{l}\text { Bacterial wilt (Ralstonia } \\
\text { solanacearum) and } \\
\text { Fusarium wilt (Fusarium } \\
\text { oxysporum). }\end{array}$ & $\begin{array}{l}\text { Tomato wilt severity was } \\
\text { reduced by } 25 \% \text { with Glomus } \\
\text { mosseae relative to the control. }\end{array}$ & Taiwo et al. [133]. \\
\hline Chemical control & $\begin{array}{c}\text { Geranium } \\
\text { (Pelargonium hortorum). }\end{array}$ & $\begin{array}{l}\text { Using bactericides in } \\
\text { irrigation water will protect } \\
\text { geranium plants from } \\
\text { Bacterial wilt. }\end{array}$ & $\begin{array}{l}\text { Bacterial wilt (Ralstonia } \\
\text { solanacearum). }\end{array}$ & $\begin{array}{l}\text { Phosphoric acid inhibited } \\
\text { in vitro growth of } R \text {. } \\
\text { solanacearum. K and phosphoric } \\
\text { acid salt (K-Phite) were very } \\
\text { effective in protecting plants } \\
\text { from infection at } \\
6 \times 10^{6} \mathrm{CFU} / \mathrm{g} \text { soil. }\end{array}$ & Norman et al. [134]. \\
\hline
\end{tabular}




\subsection{Farming Practices to Improve Soil Health Component}

\subsubsection{Organic Farming}

The interest of organic farming as the most sustainable agricultural system is rapidly growing worldwide because it not only improves the physical, biological, and environmental resources such as soil nutrient mineralization, microbial activity, abundance and diversity, and groundwater quality [lower nitrate $\left(\mathrm{NO}_{3}{ }^{-}\right)$concentrations], but also yield and product quality as evidenced in wheat, potato, watermelon, and strawberry (Figure 4) [135-138]. The United States Department of Agriculture defines organic farming as "a production system that is managed in accordance with the laws and regulations in this part to respond to site-specific conditions by integrating cultural, biological, and mechanical practices that foster cycling of resources, promote ecological balance, and conserve biodiversity" [139]. Leguminous crops (e.g., Sesbania spp. and alfalfa) that are used widely in organic farming have been known to increase soil organic matter (Sesbania rostrata yielded 16.8 ton ha ${ }^{-1} \mathrm{dry}$ matter in 13 weeks), $\mathrm{N}$ supply capacity and soil $\mathrm{N}$ sequestration by about $50 \%$ (compared to mineral fertilization) [136,140]. A long-term (12 year) study with rice (Oryza sativa) and corn (Zea mays) crops showed that organic systems using compost and peat sources had higher microbial population and enzyme activities compared to conventional systems [141]. The diversity and dominant soil bacterial population ( $\beta$-proteobacteria, acidobacteria, and $\alpha$-proteobacteria) in organic and conventional banana (Musa acuminata) plantations was significantly higher in organic systems [142]. Growing vegetable crops such as tomato (Solanum lycopersicum), snap bean (Phaseolus vulgaris) and lettuce (Lactuca sativa) under organic and conventional culture for three years revealed that organic farming using compost increased soil $\mathrm{CO}_{2}$ respiration (soil health indicator) and enzyme activities (fluorescein diacetate hydrolysis, phosphatase, and arylsulphatase activities) compared to conventional mineral fertilizer (NPK) [143]. Also, organic culture proved to suppress soil pathogens, such as Fusarium wilt in cucumber (Cucumis sativus) [144] and plant parasitic nematodes Pratylenchus and Meloidogyne in maize and bean compared to conventional culture systems [145].

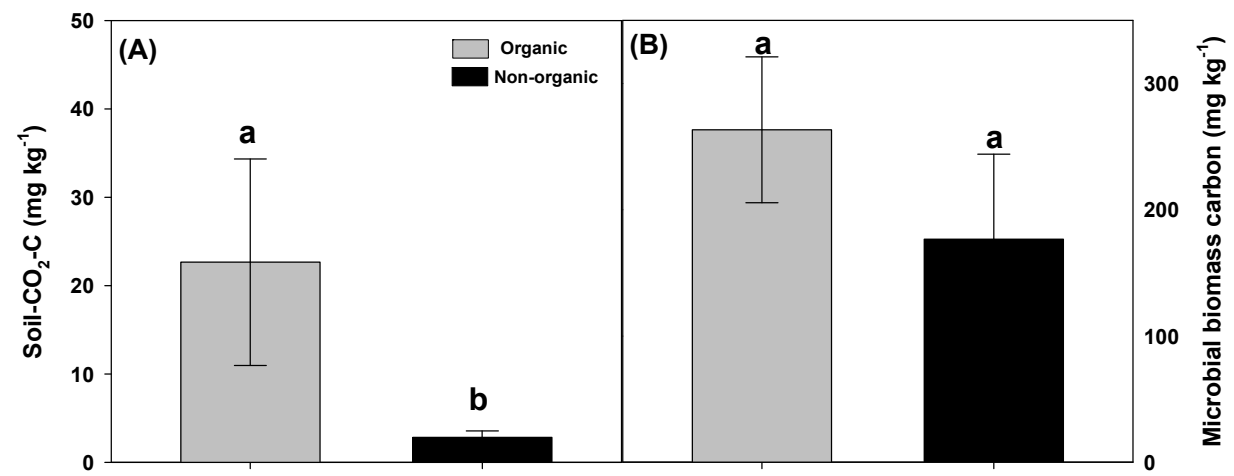

Figure 4. (A). Soil respiration $\left(\mathrm{CO}_{2}-\mathrm{C}\right)$ and (B) microbial biomass carbon for organic and conventional soil. Soil respiration represent the mean of four studies (Chang et al. [146]; Iovieno et al. [143]; Leskovar and Othman [16]; Othman and Leskovar [147]). For microbial biomass carbon, data were from Chang et al. [146]; Mangalassery et al. [148]; Mäder et al. [137]. Bars represent mean \pm standard error. Different letters indicate a significant difference between treatments $(p<0.05)$.

Yield gap is defined as the difference between potential yield and actual yield under the same environment [149]. The key point in the debate on crop yield gap between organic and conventional agriculture and the contribution of organic farming to global agriculture is whether organic farming can economically address global food demands. A meta-dataset of 362 research studies from 43 countries worldwide ( $85 \%$ of the data coming from Europe and North America) showed that current organic farming yields of individual crops are on average $80 \%$ of conventional yields (standard deviation $21 \%$ ). Relative yields differed between crops with soybean, rice, and corn scoring higher than $80 \%$ and wheat, barley, and potato scoring lower than 80\%. Except for countries with very intensive agricultural 
systems (e.g., Netherlands where the conventional yield gap was significantly larger), most studied regions had relative yields fairly close to the overall average [150].

Organic farming can improve soil physical and chemical properties. For example, organic systems in a clay soil increased soil water content $(\sim 15 \%)$ and retention capacity $(10 \%)$ and reduced soil bulk density $(8 \%)$ in the top $20 \mathrm{~cm}$ soil layer as compared to conventional systems [151]. In addition, organic farming is a good source of macro-nutrients (Table 2). For example, in a long-term (18 years) study using chemical and organic fertilization regimes, $\mathrm{N}$ storage of organic manure treated soil was significantly higher $(50 \%)$ in the $20 \mathrm{~cm}$ topsoil than conventional chemical fertilizers [136]. In another long-term study (21 years) of organic and conventional farming, nutrient input (N, P, K) in the organic soil was 34 to $51 \%$ lower than in the conventional, whereas $\mathrm{Ca}^{2+}$ and $\mathrm{Mg}^{2+}$ were (30-50\%) higher [137].

Short-term, conventional farming normally has a greater capacity to increase yield compared to organic farming [16]. In addition, organic farming is more costly for growers due to the high labor demand for weed and pest control and the lack of uniformity and stability of organic fertilizers [155]. The main challenge in organic farming is to synchronize nutrient release, specifically $\mathrm{N}$, with seasonal growth demand of crops [155]. Organic materials do not release adequate amount of $\mathrm{N}$ to succeeding crops beyond 6 to 8 weeks after incorporation [155]. Low $\mathrm{N}$ supply during the crop growth stages leads to a reduction in leaf chlorophyll content, inefficient water use and subsequently lower growth and yield [156,157]. In a recent study in globe artichoke, plants grown following conventional farming had higher growth and yield than those from organic farming [16]. That study also showed that soil amendment using organic farming reduced soil $\mathrm{NO}_{3}{ }^{-}, \mathrm{P}, \mathrm{K}, \mathrm{Mg}^{2+}$ and increased $\mathrm{Ca}^{2+}$ compared to conventional, while significantly improving soil respiration- $\mathrm{CO}_{2}$ (soil health indicator) by 20-fold compared to conventional. In addition, the organic system increased head quality components, specifically chlorogenic acid by $31 \%$ and cynarin by $12 \%$ compared to the conventional system. Similarly, organic soil amendments (organic vs conventional fertilizers) increased marketable yield, ascorbic acid and phenolic compounds in collard (Brassica oleracea) and kale (Brassica oleracea) [158]. Meta-data studies of conventional and organic growing systems showed that organic products (fruits, vegetables, and grains) had lower $\mathrm{NO}_{3}{ }^{-}$content and pesticide residue levels and higher nutrient $\left(\mathrm{Fe}^{3+}\right.$, $\left.\mathrm{Mg}^{2+}, \mathrm{P}\right)$ and vitamin C $[159,160]$.

Although organic farming is less productive than conventional, organic yield can approach the same productivity after cropping for 10-13 years [138]. Overall, organic farming is the best system to improve soil and fruit quality, but it may not be the best option for farmers (short-term) when yield is the primary target [16]. Therefore, a productivity gap between organic and conventional systems can be a matter of time, and that long-term organic farming may result in higher stability of soil microbial communities and soil processes [138]. 
Table 2. Mean values of aggregated soil data from organic and conventional farms at the end of the experimental period.

\begin{tabular}{|c|c|c|c|c|c|}
\hline Crop & Soil Type & $\begin{array}{l}\text { Study Period } \\
\text { (Year) }\end{array}$ & Nutrient & Response & Reference \\
\hline Citrus (Citrus $\times$ sinensis) & $\begin{array}{l}\text { Clay soil (Oxisols soil, } 50 \% \\
\text { Clay, } 20 \% \text { silt; } 30 \% \text { sand). }\end{array}$ & 6 & $\mathrm{~N}$ & $\begin{array}{l}\text { The organic system had } 2 \text { ton ha }{ }^{-1} \text { more } \\
\mathrm{N}(p<0.05) \text { stocked at } 0-100 \mathrm{~cm} \text { than in } \\
\text { conventional system. }\end{array}$ & Escanhoela et al. [152]. \\
\hline $\begin{array}{l}\text { Wheat (Triticum aestivum) } \\
\text { maize (Zea mays) rotation }\end{array}$ & $\begin{array}{l}\text { Sandy loam soil } \\
\text { (aquic inceptisol). }\end{array}$ & 18 & $\mathrm{~N}$ & $\begin{array}{l}\text { Organic soil had } 5-22 \% \text { more } \mathrm{N}(p<0.05) \\
\text { than conventional. }\end{array}$ & Gong et al. [136]. \\
\hline $\begin{array}{l}\text { Wheat, potatoes } \\
\text { (Solanum tuberosum), and } \\
\text { clover (Trifolium sp.) }\end{array}$ & Clay soil. & 21 & $\mathrm{P}, \mathrm{K}, \mathrm{Ca}^{2+}, \mathrm{Mg}^{2+}$ & $\begin{array}{c}\text { Organic farming had higher }(p<0.05) \\
\mathrm{Ca}^{2+} \text {, and } \mathrm{Mg}^{2+} \text { than conventional. } \\
\text { Organic }\left(\mathrm{mg} \mathrm{kg}^{-1}\right): 16 \mathrm{P}, 90 \mathrm{~K}, 2100 \mathrm{Ca}^{2+}, \\
144 \mathrm{Mg}^{2+} \cdot \\
\text { Conventional }\left(\mathrm{mg} \mathrm{kg}^{-1}\right): 14 \mathrm{P}, 95 \mathrm{~K}, \\
1700 \mathrm{Ca}^{2+}, 94 \mathrm{Mg}^{2+} .\end{array}$ & Mäder et al. [137]. \\
\hline $\begin{array}{c}\text { Artichoke } \\
\text { (Cynara cardunculus) }\end{array}$ & $\begin{array}{l}\text { Clay soil (hyperthermic } \\
\text { Aridic Calciustolls). }\end{array}$ & 2 & $\begin{array}{c}\mathrm{NO}_{3}^{-}, \mathrm{P}, \mathrm{K}, \mathrm{Ca}^{2+}, \mathrm{Mg}^{2+}, \\
\mathrm{S}, \mathrm{Na}\end{array}$ & $\begin{array}{c}\text { Organic soil had lower } \mathrm{NO}_{3}^{-}, \mathrm{P}, \mathrm{K} \text { and } \\
\mathrm{Mg}^{+2} \text { and higher } \mathrm{Ca}^{+2} \text { and } \mathrm{Na} \text { than } \\
\text { conventional. } \mathrm{NO}_{3}^{-}, \mathrm{P}, \mathrm{K}^{2} \mathrm{Mg}^{+2}, \mathrm{Ca}^{+2} \\
\text { and Na were significant at } p<0.05 \text {. } \\
\text { Organic }\left(\mathrm{mg} \mathrm{kg}^{-1}\right): 5 \mathrm{NO}_{3}^{-}-\mathrm{N}, 34 \mathrm{P} \\
588 \mathrm{~K}, 11,200 \mathrm{Ca}^{2+}, 263 \mathrm{Mg}^{2+}, 15.8 \mathrm{~S} \\
64 \mathrm{Na} \text {. Conventional }\left(\mathrm{mg} \mathrm{kg}^{-1}\right) \\
22 \mathrm{NO}_{3}-\mathrm{N}^{-} 62 \mathrm{P}, 669 \mathrm{~K}, 10,800 \mathrm{Ca}^{2+} \\
307 \mathrm{Mg}^{+2}, 16.3 \mathrm{~S}, 28 \mathrm{Na} \text {. }\end{array}$ & $\begin{array}{c}\text { Leskovar and Othman } \\
{[16] .}\end{array}$ \\
\hline $\begin{array}{c}\text { Cashew } \\
\text { (Anacardium occidentale) }\end{array}$ & $\begin{array}{c}\text { Loamyskeletal, mixed } \\
\text { isohyperthermic Ustic } \\
\text { Haplohumults. }\end{array}$ & 5 & $\mathrm{~N}$ & $\begin{array}{c}\text { Available } \mathrm{N} \text { in organic was higher } \\
\left(p<0.05,435 \mathrm{~kg} \mathrm{ha}^{-1}\right) \text { than conventional } \\
\left(402 \mathrm{~kg} \mathrm{ha}^{-1}\right) .\end{array}$ & Mangalassery et al. [148] \\
\hline $\begin{array}{c}\text { Cowpea } \\
\text { (Vigna unguiculata) }\end{array}$ & Loamy soil. & 4 & $\begin{array}{l}\mathrm{N}, \mathrm{P}, \mathrm{K}, \mathrm{Ca}^{2+}, \mathrm{Mg}^{2+}, \mathrm{Fe} \\
\mathrm{Mn}, \mathrm{Zn} \text { and } \mathrm{Cu}\end{array}$ & $\begin{array}{c}\text { Organic farming increased available } \mathrm{P}, \mathrm{K}, \\
\text { Fe, and reduced total } \mathrm{N} \text { compared to } \\
\text { conventional. } \mathrm{N}, \mathrm{P}, \mathrm{K}, \text { Fe were significant } \\
\text { at } p<0.05 \text {. } \\
\text { Organic: }\left(73 \mathrm{~N}, 111 \mathrm{P}, 359 \mathrm{~K} \mathrm{~kg} \mathrm{~h}^{-1}\right), \\
\left(3500 \mathrm{Ca}^{2+}, 1200 \mathrm{Mg}^{2+}, 80 \mathrm{Fe}, 17 \mathrm{Mn}^{2+},\right. \\
5.5 \mathrm{Zn}, 1.3 \mathrm{Cu} \mathrm{mg} \mathrm{kg}^{-1} . \\
\text { Conventional: }\left(86 \mathrm{~N}, 96 \mathrm{P}, 192 \mathrm{~K} \mathrm{~kg} \mathrm{~h}^{-1}\right), \\
\left(2400 \mathrm{Ca}^{2+}, 900 \mathrm{Mg}^{2+}, 70 \mathrm{Fe}, 15 \mathrm{Mn}^{2+},\right. \\
\left.4.3 \mathrm{Zn}, 1.2 \mathrm{Cu} \mathrm{mg} \mathrm{kg}^{-1}\right) .\end{array}$ & Suja et al. [153]. \\
\hline $\begin{array}{c}\text { Broccoli (Brassica oleracea), } \\
\text { lettuce (Lactuca sativa), } \\
\text { potato (Solanun } \\
\text { tuberosum), and carrot } \\
\text { (Dancus carota) }\end{array}$ & Loamy soil (Xerofluvent). & 5 & $\mathrm{Fe}, \mathrm{Mn}^{2+}, \mathrm{Zn}$ and $\mathrm{Cu}$ & $\begin{array}{l}\text { The available nutrients in organic were } \\
\text { statistically similar to conventional fields. }\end{array}$ & Maqueda et al. [154]. \\
\hline
\end{tabular}


Crop rotation with legumes usually provides the most $\mathrm{N}$ for organic farming systems. However, providing adequate amount of $\mathrm{N}$ to crops in organic culture can be challenging because the nutrient (specifically N) release process is quite slow compared to mineral fertilizers [155]. Therefore, growers use plant- and animal-based organic fertilizers to meet the essential crop requirements. However, commercially available organic fertilizers are more costly than chemical fertilizers [156], because they are more difficult to produce and require large biomass (plant-based fertilizers) to guarantee consistently positive plant responses. Therefore, the choice of plant- or animal-based organic fertilizer is critical to sustain crop yield and gain profits in organic farming. Several plant-based (e.g., leguminous crop and maize meals) and animal-based (e.g., blood and fish meals, feathers, bones, and composted-manure) fertilizers are available commercially for organic growers [156,161]. Plant-based fertilizers such as leguminous crops have been used widely as green manures to increase the available $\mathrm{N}$ in the soil $[162,163]$. Legumes can fix atmospheric $\mathrm{N}$ in the soil, reduce the risk of $\mathrm{NO}_{3}{ }^{-}$leaching, improve soil physical and chemical properties as well as fruit quality $[162,164]$. In artichoke, organic soil amended with alfalfa meal had higher soil respiration (soil health indicator) and head phytochemicals than soil amended with animal-based fertilizers (fish meal, blood meal, and chicken manure) [147]. However, artichoke grown in soil amended with animal-based fertilizer (chicken manure) had higher head yield and input cost (N: \$US $31 \mathrm{~kg}^{-1}$ for blood meal, \$US $28 \mathrm{~kg}^{-1}$ for chicken manure, \$US $44 \mathrm{~kg}^{-1}$ for fish meal, and \$US $74 \mathrm{~kg}^{-1}$ for alfalfa meal) than those amended using, alfalfa meal [147]. Long-term, plant-based fertilizers (leguminous crop and maize meals) can be an ideal choice for improving soil health, while animal-based (blood and fish meals, feathers, bones and composted-manure) may be a superior option for organic growers when yield and cost are the main concerns, especially short-term.

\subsubsection{Tillage Practices}

Tillage practices affect soil chemical and physical properties, as well as fruit quality and crop yield as reported in watermelon and rice-maize cropping systems $[9,165]$. Adopting useful tillage practice is a prerequisite to sustain soil health and crop production [166]. Conservation tillage practices (no-tillage, reduced, and strip) can increase soil microbial activities, soil moisture, organic matter, aggregate stability, cation exchange capacity and crop yield $[9,165,167,168]$. Conservation tillage using permanent beds and strip tillage can potentially increase farmer net income (Table 3) and benefit; cost ratio by increased plant water use efficiency and reduced irrigation water and labor use compared to conventional $[165,169]$. Al-Kaisi et al. [170] also found that tillage intensity significantly reduced soil macro- and micro-aggregate stability. Conservation tillage practices increased soil available $P$ in the topsoil $(0-20 \mathrm{~cm})$ by $3.8 \%$, K by $13.6 \%$ and soil organic matter by $0.17 \%$ compared to conventional [171]. Maintaining crop residues on the top soil surface layer (full cover, no till; partial cover, strip tillage) can also reduce soil erosion and increases soil moisture content [172,173]. 
Table 3. Effect of tillage practices on irrigation, water use efficiency (WUE), and net returns.

\begin{tabular}{|c|c|c|c|c|}
\hline \multicolumn{5}{|c|}{ Conservational Tillage vs. Conventional } \\
\hline Crop & Irrigation Water Applied & Total Increase in WUE & $\begin{array}{c}\text { Total Increase in Net Returns } \\
\text { in U \$ S }\end{array}$ & Reference \\
\hline Maize & $\begin{array}{l}\text { Reduced irrigation water by } \\
25 \% .\end{array}$ & $16 \%$. & $\$ 281 \mathrm{ha}^{-1}$ & Jat et al. [169]. \\
\hline Rice-Wheat & $\begin{array}{l}\text { Reduced irrigation water by } \\
\qquad 12-20 \% .\end{array}$ & $\begin{array}{l}1.4 \mathrm{~kg} \text { grain per } \mathrm{m}^{3} \text { input water } \\
\text { compared to } 0.75 \\
\text { for conventional. }\end{array}$ & $\$ 184-280 \mathrm{ha}^{-1}$ & Jat et al. [174]. \\
\hline Rice-Wheat & $\begin{array}{l}\text { Reduced irrigation water by } \\
16 \text { to } 18 \% .\end{array}$ & $4.2 \%$ & $\$ 49-96 \mathrm{ha}^{-1}$ & Saharawat et al. [175]. \\
\hline Wheat & $\begin{array}{c}\text { Fuel consumption efficiency } \\
\text { (energy) for irrigation was } \\
21 \% \text { higher. }\end{array}$ & $\begin{array}{l}4.5 \mathrm{t} \text { grains per ha } \mathrm{h}^{-1} \text { compared } \\
\text { to } 4.109 \mathrm{t} \mathrm{ha}^{-1} \text { for conventional. }\end{array}$ & $\begin{array}{l}\text { Net income in zero-tillage was } \\
33 \% \text { higher than conventional. }\end{array}$ & Vivak et al. [176]. \\
\hline Rice-Wheat & $\begin{array}{l}\text { Reduced irrigation water } \\
13 \text { to } 23 \% \text {. }\end{array}$ & $\begin{array}{c}-5 \% \text { (conventional was } \\
5 \% \text { higher). }\end{array}$ & $\begin{array}{l}\$ 62 \mathrm{ha}^{-1} \text { for year } 1 \text {; similar in } \\
\text { year } 2 \text {. Weed management } \\
\text { incurred higher cost than with } \\
\text { conventional systems. }\end{array}$ & Bhushan et al. [177]. \\
\hline Wheat & No data. & $\begin{array}{l}\text { 6.5-11.6 }\left(\mathrm{kg} \mathrm{ha}^{-1} / \mathrm{mm}\right) \\
\text { compared with } 4.05 \text { to } 7.5 \text { for } \\
\text { conventional. }\end{array}$ & $\begin{array}{l}\text { No-tillage resulted in } \\
520 \mathrm{~kg} \mathrm{ha}^{-1} \text { greater wheat grain } \\
\text { yield than conventional. }\end{array}$ & Mohammad et al. [178] \\
\hline Wheat-Maize & $\begin{array}{l}\text { Mean soil water storage } \\
\text { measured at } 0-2 \mathrm{~m} \text { depth for } \\
\text { no-tillage was } 412 \mathrm{~mm} \\
\text { compared to } 392 \mathrm{~mm} \\
\text { for conventional. }\end{array}$ & Not significant. & $\$ 57 \mathrm{ha}^{-1}$. & Zhang et al. [179]. \\
\hline Wheat-Maize & $\begin{array}{l}\text { Reduced irrigation water } \\
\text { consumption by } 19 \% .\end{array}$ & $\begin{array}{l}24.6 \% \text { for wheat and } 15.9 \% \\
\text { for maize. }\end{array}$ & $\begin{array}{l}\text { Wheat yield increased by } 10.3 \% \\
\text { and maize yield by } 17.4 \% .\end{array}$ & Shao et al. [171]. \\
\hline
\end{tabular}


However, studies that evaluated tillage practices (conservation and conventional) are controversial with respect to changes in soil microorganism and soil physical properties. Conservation tillage increase bacterial and fungi abundance and nematode, earthworm, and gram-positive bacteria than conventional system (Figure 5) [10,180,181]. A 10-year study on tillage practices on tomato production found that the total number of nematode under conventional tillage (moldboard plow) was 52\% lower than of conservation strip tillage [182]. Nematode community composition (expressed as individuals per $500 \mathrm{~cm}^{3}$ soil) in strip tillage field measured in the fall contained individuals as follow: bacterivores 1900, fungivores 40, omnivorous 283 , predacious 37 , and root-feeding nematodes (plant parasitic) 1869. For moldboard plow soil, bacterivores individuals were 407 , omnivorous 67 , predacious 14 , and root-feeding nematodes 350 , with no detected fungivores. However, nematode abundance does not necessary equate to soil health nor function. For example, strip tillage increased total bacteria by $49 \%$, active bacteria by $27 \%$, active and total fungi by $37 \%$, and total nematodes by $275 \%$ when compared to conventional tillage [10]. However, the same study showed that strip tillage potentially reduced soil nutrient content $\left(\mathrm{P}\right.$ and $\mathrm{NO}_{3}{ }^{-}-\mathrm{N}$ ) and increased ( 9-fold) root-feeding nematodes (harmful to plant roots) as compared to conventional [10]. This could be attributed to the feeding behavior of nematodes and the reproductive rate, which respond quickly to rhizosphere changes. Conservation tillage provides superior feeding sources for nematodes than conventional (i.e., higher number bacteria and fungi). A major disadvantage of conservation tillage practices, particularly no tillage systems, is the higher weed pressure management [183]. No-tillage can also lead to higher soil bulk density and compaction (higher penetrometer resistance) in the top soil layer [168]. Conversely, conventional tillage practices aerates soil surface and reduces compaction, reduces weeds pressure, and incorporates crop residues and fertilizers [184].

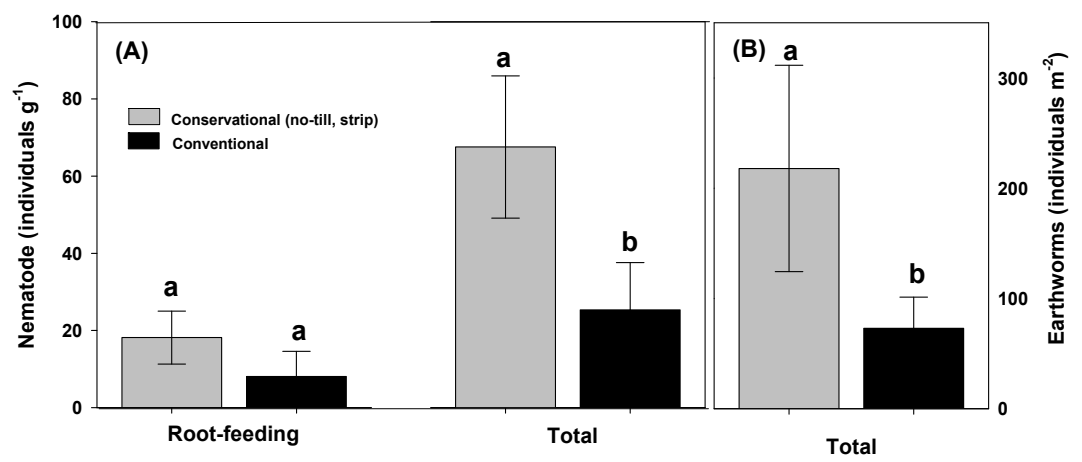

Figure 5. (A) Nematode community composition (root-feeding nematode and total) and (B) earthworm abundance for conventional and conservational systems. Each nematode graph represents the mean of three studies Overstreet et al. [182]; Ito et al. [185] and Leskovar et al. [9]. For earthworm abundance, data were from Melman et al. [186]; Crittenden et al. [14]; Johnson-Maynard et al. [187]; van Schaik et al. [188]. Bars represent mean \pm standard error. Different letters indicate a significant difference between treatments $(p<0.05)$.

\section{Conclusions}

This review examined the role of soil health in intensive crop production systems and identified factors to consider when assessing soil health components in sustainable agricultural systems. Soil health considers soil biota component such as microorganism abundance, diversity, activity, and community stability. The diversity and abundance of soil and rhizosphere microorganisms influence plant composition, productivity, and sustainability. AMF enhance water use efficiency and nutrient availability to plants. Cyanobacteria adapted to a wide range of harsh environmental conditions, represent a consistent renewable biomass source of soluble organic matters known as secondary metabolites, acting as a growth promoters and supporting agricultural crop productivity. The soil profile contains several types of harmful and beneficial nematodes. Harmful nematodes feed on plant roots and reduce their productivity; while beneficial nematodes play a key role in 
soil nutrient cycling for better soil health. Organic system increases soil nutrient mineralization, and microorganism abundance and diversity as well as soil physical properties. Interestingly, organic fertilizer source (plant- or animal-based) can potentially affect microorganism abundance and crop yield. While plant-based fertilizer increases soil microbial abundance, animal-based fertilizer has higher crop yield and lower number of microorganisms. However, organic cultural practices are more costly due to high labor cost and lack of uniformity and stability of organic fertilizers. Overall, plant-based farming can be an ideal practice to increase soil and fruit quality, while animal-based fertilizer would be the preferred for organic farmers seeking higher yield at relatively lower input cost of fertilizers. For tillage practices, conservation tillage (no-tillage, reduced, and strip) improve soil health by enhance soil fungi abundance and activity, earthworm diversity, organic matter, aggregate stability, and caution exchange capacity. In fact, conservation tillage such no-till reduced irrigation water applied (12-25\%) and increased water use efficiency (16-24\%) and total net returns (\$49-281) compared to conventional (e.g., mouldboard, harrow followed with cultivator). However, conservation tillage might increase root-feeding nematodes (harmful to plant roots) compared to conventional. Improved assessment of soil health indicators is necessary to further enhance our understanding on how production strategies and environmental factors affect the physical, biological, and chemical stability and dynamics of the soil-rhizosphere-plant systems and their impact to short or long term sustainability.

Author Contributions: M.M.T., Y.A.O., K.M.A., writing; D.I.L., reviewing and editing. All authors have read and agreed to the published version of the manuscript.

Funding: This research received no external funding.

Conflicts of Interest: The authors declare no conflict of interest.

\section{References}

1. Doran, J.W.; Zeiss, M.R. Soil health and sustainability: Managing the biotic component of soil quality. Appl. Soil Ecol. 2000, 15, 3-11. [CrossRef]

2. Lichtfouse, E.; Navarrete, M.; Debaeke, P.; Souchere, V.; Alberola, C.; Menassieu, J. Agronomy for sustainable agriculture. A review. Agron. Sustain. Dev. 2009, 29, 1-6. [CrossRef]

3. Doran, J.W. Soil health and global sustainability: Translating science into practice. Agric. Ecosyst. Environ. 2002, 88, 119-127. [CrossRef]

4. Timsina, J. Can organic sources of nutrients increase crop yields to meet global food demand? Agronomy 2018, 8, 214. [CrossRef]

5. Devarinti, S.R. Natural Farming: Eco-Friendly and Sustainable? Agrotechnology 2016, 5, 147. [CrossRef]

6. Singh, J.S.; Pandey, V.C.; Singh, D.P. Efficient soil microorganisms: A new dimension for sustainable agriculture and environmental development. Agric. Ecosyst. Environ. 2011, 140, 339-353. [CrossRef]

7. Lal, R. Soils and sustainable agriculture. A review. Agron. Sustain. Dev. 2008, 28, 57-64. [CrossRef]

8. Berendsen, R.L.; Pieterse, C.M.; Bakker, P.A. The rhizosphere microbiome and plant health. Trends Plant Sci. 2012, 17, 478-486. [CrossRef]

9. Sahu, P.; Singh, D.; Prabha, R.; Meena, K.; Abhilash, P. Connecting microbial capabilities with the soil and plant health: Options for agricultural sustainability. Ecol. Indic. 2019, 105, 601-612. [CrossRef]

10. Leskovar, D.; Othman, Y.; Dong, X. Strip tillage improves soil biological activity, fruit yield and sugar content of triploid watermelon. Soil Tillage Res. 2016, 163, 266-273. [CrossRef]

11. Meena, R.; Bohra, J.; Singh, S.; Meena, V.; Verma, J.; Verma, S.; Sihag, S. Towards the prime response of manure to enhance nutrient use efficiency and soil sustainability a current need: A book Review. J. Clean. Prod. 2016, 1258-1260. [CrossRef]

12. Dotaniya, M.; Meena, V.; Basak, B.; Meena, R. Potassium uptake by crops as well as microorganisms. In Potassium Solubilizing Microorganisms for Sustainable Agriculture; Meena, V.S., Maurya, B.R., Verma, J.P., Meena, R.S., Eds.; Springer: New Delhi, India, 2016; pp. 267-280.

13. Van der Heijden, M.; Bardgett, R.; van Straalen, N. The unseen majority: Soil microbes as drivers of plant diversity and productivity in terrestrial Ecosystems. Ecol. Lett. 2008, 11, 296-310. [CrossRef] [PubMed] 
14. Singh, J.S. Plant-Microbe Interactions: A Viable Tool for Agricultural Sustainability Plant Microbes Symbiosis: Applied Facets; Arora, N.K., Ed.; Springer: New Delhi, India; Heidelberg, Germany; New York, NY, USA; Dordrecht, The Netherlands; London, UK, 2015; p. 384.

15. Al-Karaki, G.; Othman, Y.; Al-Ajmi, A. Effects of mycorrhizal fungi inoculation on landscape turf establishment under Arabian Gulf region conditions. Arab GulfJ. Sci. Res. 2007, 25, 147-152.

16. Leskovar, D.; Othman, Y. Organic and conventional farming differentially influenced soil respiration, physiology, growth, and head quality of artichoke cultivars. J. Soil Sci. Plant Nutr. 2018, 18, 865-880. [CrossRef]

17. Das, A.; Patel, D.P.; Kumar, M.; Ramkrushna, G.I.; Mukherjee, A.; Layek, J.; Ngachan, S.V.; Buragohain, J. Impact of seven years of organic farming on soil and produce quality and crop yields in eastern Himalayas, India. Agric. Ecosyst. Environ. 2017, 236, 142-153. [CrossRef]

18. Crittenden, S.; Eswaramurthy, T.; de Goede, R.; Brussaard, L.; Pulleman, M. Effect of tillage on earthworms over short- and medium-term in conventional and organic farming. Appl. Soil Ecol. 2014, 83, 140-148. [CrossRef]

19. Turbé, A.; De Toni, A.; Benito, P.; Lavelle, P.; Lavelle, P.; Ruiz, N.; Van der Putten, W.; Labouze, E.; Mudgal, S. Soil Biodiversity: Functions, Threats and Tools for Policy Makers. Report for European Commission, DG Environment. 2010. Available online: https:/ec.europa.eu/environment/archives/soil/pdf/biodiversity_ report.pdf (accessed on 8 June 2020).

20. Gomiero, T. Soil degradation, land scarcity and food security: Reviewing a complex challenge. Sustainability 2016, 8, 281. [CrossRef]

21. Jacoby, R.; Peukert, M.; Succurro, A.; Koprivova, A.; Kopriva, S. The role of soil microorganisms in plant mineral nutrition-current knowledge and future directions. Front. Plant Sci. 2017, 8, 1617. [CrossRef] [PubMed]

22. Yang, G.; Wagg, C.; Veresoglou, S.; Hempel, S.; Rillig, M. How soil biota drive ecosystem stability. Trends Plant Sci. 2018, 23, 1057-1067. [CrossRef] [PubMed]

23. Bach, E.M.; Wall, D.H. Trends in Global Biodiversity: Soil Biota and Processes. In The Encyclopedia of the Anthropocene; DellaSala Dominick, A., Goldstein Michael, I., Eds.; Elsevier: Oxford, UK, 2018; Volume 3, pp. 125-130. [CrossRef]

24. Bardgett, R.; van der Putten, W. Belowground biodiversity and ecosystem functioning. Nature 2014, 515, 505-511. [CrossRef]

25. Serna-Chavez, H.M.; Fierer, N.; Van Bodeom, P.M. Global drivers and patterns of microbial abundance in soil. Glob. Ecol. Biogeogr. 2013, 22, 1162-1172. [CrossRef]

26. Orgiazzi, A.; Bardgett, R.D.; Barrios, E.; Behan-Pelletier, V.; Briones, M.J.I.; Chotte, J.L.; De Deyn, G.B.; Eggleton, P.; Fierer, N.; Fraser, T.; et al. Global Soil Biodiversity Atlas; European Commission, Publications Office of the European Union: Luxembourg, 2016; p. 176; Available online: https://esdac.jrc.ec.europa.eu/ content/global-soil-biodiversity-maps-0 (accessed on 11 June 2020).

27. Ritz, K.; Black, H.I.J.; Campbell, C.D.; Harris, J.A.; Wood, C. Selecting the biological indicators for monitoring soils: A framework for balancing scientific and technical opinion to assist policy development. Ecol. Indic. 2009, 9, 1212-1221. [CrossRef]

28. Handa, I.T.; Aerts, R.; Berendse, F.; Berg, M.P.; Bruder, A.; Butenschoen, O.; Chauvet, E.; Gessner, M.O.; Jabiol, J.; Makkonen, M. Consequences of biodiversity loss for litter decomposition across biomes. Nature 2014, 509, 218-221. [CrossRef] [PubMed]

29. Whalen, J. Managing soil biota-mediated decomposition and nutrient mineralization in sustainable agroecosystems. Adv. Agric. 2014, 1-13. [CrossRef]

30. Karlen, D.L.; Ditzler, C.; Andrews, S.S. Soil quality: Why and how? Geoderma 2003, 114, 145-156. [CrossRef]

31. Sahu, N.; Vasu, D.; Sahu, A.; Lal, N.; Singh, S.K. Strength of Microbes in Nutrient Cycling: A Key to Soil Health. In Agriculturally Important Microbes for Sustainable Agriculture; Meena, V., Mishra, P., Bisht, J., Pattanayak, A., Eds.; Springer: Singapore, 2017; pp. 69-86. [CrossRef]

32. Karlen, D.; Mausbach, M.; Doan, J.; Cline, R.; Harris, R.; Schuman, G. Soil quality: A concept definition and framework or evaluation. Soil Sci. Soc. Am. J. 1997, 61, 4-10. [CrossRef]

33. Bouma, J.; van Ittersum, M.; Stoorvogel, J.; Batjes, N.; Droogers, P.; Pulleman, M. Soil capability: Exploring the functional potentials o soil. In Global Soil Security; Springer: Cham, Switzerland, 2017; pp. 27-44. 
34. Tóth, G. Agri-Environmental Soil Quality Indicator in the European Perspective; European Commission Joint Research Centre, OECD: Ispra, Italy, 2008; p. 12.

35. Chaussod, R. La qualité biologique des sols: Des concepts aux applications. Comptes Rendus de l'Académie d'Agriculture de France 2002, 88, 61-68.

36. Acton, D.; Gregorich, L. Understanding soil health. In The Health of Our Soil; Acton, D.F., Gregorich, L.J., Eds.; Towards sustainable agriculture in Canada; Centre or Land and Biological Resources Research Branch, Agriculture and Agri-Food Canada: Ottawa, ON, Canada, 1995; p. 138.

37. More, S.D. Soil quality indicators or sustainable crop productivity. J. Indian Soc. Soil Sci. 2010, 58, 5-11.

38. Lal, R. Restoring soil quality to mitigate soil degradation. Sustainability 2015, 7, 5875-5895. [CrossRef]

39. Harris, J. Soil microbial communities and restoration ecology: Facilitators or followers? Science 2009, 325, 573-574. [CrossRef]

40. Altieri, M.A.; Nicholls, C.I. Soil fertility management and insect pests: Harmonizing soil and plant health in agroecosystems. Soil Tillage Res. 2003, 72, 203-211. [CrossRef]

41. Giller, K.; Bignell, D.; Lavelle, P.; Swift, M.; Barrios, E.; Moreia, F.; van Noordwijk, M.; Barois, I.; Karanja, N.; Huising, J. Soil Biodiversity in Rapidly Changing Tropical Landscapes: Scaling down and Scaling up. In Biological Diversity and Function in Soils (Ecological Reviews); Bardgett, R., Usher, M., Hopkins, D., Eds.; Cambridge University Press: Cambridge, UK, 2005; pp. 295-318. [CrossRef]

42. Drażkiewicz, M. Distribution of microorganisms in soil aggregates: Effect of aggregate size. Folia Microbiol. 1994, 39, 276-282. [CrossRef]

43. Tsiknia, M.; Paranychianakis, N.V.; Varouchakis, E.A.; Moraetis, D.; Nikolaidis, N.P. Environmental divers of soil microbial community distribution at the Koiliaris Critical Zone Observatory. FEMS Microbiol. Ecol. 2014, 90, 139-152. [CrossRef] [PubMed]

44. Qin, K.; Dong, X.; Jifon, J.; Leskovar, D. Rhizosphere microbial biomass is affected by soil type, organic and water inputs in a bell pepper system. Appl. Soil Ecol. 2019, 138, 80-87. [CrossRef]

45. Bowen, G.; Rovira, A. The rhizosphere and its management to improve plant growth. Adv. Agron. 1999, 66, 1-102. [CrossRef]

46. Hartmann, A.; Schmid, M.; van Tuinen, D.; Berg, G. Plant-driven selection of microbes. Plant Soil 2009, 321, 235-257. [CrossRef]

47. Rhodes, L.; Gerdeman, J. Phosphate uptake zones ofmycorrhizal and non-mycorrhizal onions. New Phytol. 1975, 75, 555-561. [CrossRef]

48. Raaijmakers, J.M.; Paulitz, T.C.; Steinberg, C.; Alabouvette, C.; Moenne-Loccoz, Y. The rhizosphere: A playground and battlefield for soilborne pathogens and beneficial microorganisms. Plant Soil 2009, 321, 341-361. [CrossRef]

49. Bonkowski, M.; Villenave, C.; Griffiths, B. Rhizosphere fauna: The functional and structural diversity of intimate interactions of soil fauna with plant roots. Plant Soil 2009, 321, 213-233. [CrossRef]

50. Mendes, R.; Garbeva, P.; Raaijmakers, J.M. The rhizosphere microbiome: Significance of plant beneficial, plant pathogenic, and human pathogenic microorganisms. FEMS Microbiol. Rev. 2013, 37, 634-663. [CrossRef]

51. Dessaux, Y.; Grandcle'ment, C.; Faure, D. Engineering the rhizosphere. Trends Plant Sci. 2016, 21, $266-278$. [CrossRef] [PubMed]

52. Zhang, Y.; Ruyter-Spira, C.; Bouwmeester, H.J. Engineering the plant rhizosphere. Curr. Opin. Biotechnol. 2015, 32, 136-142. [CrossRef] [PubMed]

53. Schnitzer, S.A.; Klironomos, J.N.; HilleRisLambers, J.; Kinkel, L.L.; Reich, P.B.; Xiao, K.; Rillig, M.C.; Sikes, B.A.; Callaway, R.M.; Mangan, S.A.; et al. Soil microbes drive the classic plant diversity-productivity pattern. Ecology 2011, 92, 296-303. [CrossRef] [PubMed]

54. Wagg, C.; Jansa, J.; Schmid, B.; van der Heijden, M.G.A. Belowground biodiversity effects of plant symbionts support aboveground productivity. Ecol. Lett. 2011, 14, 1001-1009. [CrossRef]

55. Buckling, A.; Harrison, F.; Vos, M.; Brockhurst, M.A.; Gardner, A.; West, S.A.; Griffin, A. Siderophore-mediated cooperation and virulence in Pseudomonas aeruginosa. FEMS Microbiol. Ecol. 2007, 62, 135-141. [CrossRef]

56. Cook, R.J.; Thomashow, L.S.; Weller, D.M.; Fujimoto, D.; Mazzola, M.; Bangera, G.; Kim, D.S. Molecular mechanisms of defense by Rhizobacteria against root disease. Proc. Natl. Acad. Sci. USA 1995, 92, 4197-4201. [CrossRef]

57. Raaijmakers, J.; Mazzola, M. Diversity and natural functions of antibiotics produced by beneficial and pathogenic soil bacteria. Annu. Rev. Phytopathol. 2012, 50, 403-424. [CrossRef] 
58. Schenk, S.T.; Stein, E.; Kogel, K.H.; Schikora, A. Arabidopsis growth and defense are modulated by bacterial quorum sensing molecules. Plant Signal. Behav. 2012, 7, 178-181. [CrossRef]

59. Mela, F.; Fritsche, K.; De Boer, W.; Van Veen, J.A.; De Graaff, L.H.; Van Den Berg, M.; Leveau, J.H. Dual transcriptional profiling of a bacterial/fungal confrontation: Collimonas fungivorans versus Aspergillus niger. ISME J. 2011, 5, 1494-1504. [CrossRef]

60. Kent, A.D.; Triplett, E.W. Microbial communities and their interactions in soil and rhizosphere ecosystems. Annu. Rev. Microbiol. 2002, 56, 211-236. [CrossRef]

61. Bais, H.P.; Weir, T.L.; Perry, L.G.; Gilroy, S.; Vivanco, J.M. The role of root exudates in rhizosphere interactions with plants and other organisms. Annu. Rev. Plant Biol. 2006, 57, 233-266. [CrossRef] [PubMed]

62. Mihajlović, M.; Emil, R.; Jovana, H.; Mila, G.; Brankica, T. Methods for management of soil borne plant pathogens. Pesticidi I fitomedicina 2017, 32, 9-24. [CrossRef]

63. Lucy, M.; Reed, E.; Glick, B.R. Applications of free living plant growth-promoting rhizobacteria. Antonie van Leeuwenhoek 2004, 86, 1-25. [CrossRef] [PubMed]

64. Cassán, F.; Perrig, D.; Sgroy, V.; Masciarelli, O.; Penna, C.; Luna, V. Azospirillum brasilense Az39 and Bradyrhizobium japonicum E109, inoculated singly or in combination, promote seed germination and early seedling growth in corn (Zea mays L.) and soybean (Glycine max L.). Eur. J. Soil Biol. 2009, 45, 28-35. [CrossRef]

65. Ryan, P.R.; Dessaux, Y.; Thomashow, L.S.; Weller, D.M. Rhizosphere engineering and management for sustainable agriculture. Plant Soil 2009, 321, 363-383. [CrossRef]

66. Loper, J.E.; Gross, H. Genomic analysis of antifungal metabolite production by Pseudomonas fluorescens Pf-5. Eur. J. Plant Pathol. 2007, 119, 265-278. [CrossRef]

67. Schrey, S.D.; Schellhammer, M.; Ecke, M.; Hampp, R.; Tarkka, M.T. Mycorrhiza helper bacterium Streptomyces AcH 505 induces differential gene expression in the ectomycorrhizal fungus Amanita muscaria. New Phytol. 2005, 168, 205-216. [CrossRef]

68. Jacobsen, B.J.; Zidack, N.K.; Larson, B.J. The role of Bacillus-based biological control agents in integrated pest management systems: Plant diseases. Phytopathology 2004, 94, 1272-1275. [CrossRef]

69. Long, S.R. Genes and signals in the rhizobium legume symbiosis. Plant Physiol. 2001, 125, 69-72. [CrossRef] [PubMed]

70. Morgan, J.A.; Bending, G.D.; White, P.J. Biological costs and benefits to plant-microbe interactions in the rhizosphere. J. Exp. Bot. 2005, 56, 1729-1739. [CrossRef] [PubMed]

71. Harman, G.E.; Howell, C.R.; Viterbo, A.; Chet, I.; Lorito, M. Trichoderma species- opportunistic, a virulent plant symbionts. Nat. Rev. Microbiol. 2004, 2, 43-56. [CrossRef] [PubMed]

72. Vessey, J.K. Plant growth promoting rhizobacteria as biofertilizers. Plant Soil 2003, 255, 571-586. [CrossRef]

73. Schütz, L.; Gattinger, A.; Meier, M.; Müller, A.; Boller, T.; Mäder, P.; Mathimaran, N. Improving crop yield and nutrient use efficiency via biofertilization-a global meta-analysis. Front. Plant Sci. 2018, 8, 2204. [CrossRef] [PubMed]

74. Sahu, D.; Priyadarshani, I.; Rath, B. Cyanobacteria-as potential biofertilizer. CIBTech. J. Microbiol. 2012, 1, 20-26.

75. Steenhoudt, O.; Vanderleyden, J. Azospirillum, a free-living nitrogen-fixing bacterium closely associated with grasses: Genetic, biochemical and ecological aspects. FEMS Microbiol. Rev. 2000, 24, 487-506. [CrossRef]

76. Shodo, M. Bacterial control of plant diseases. J. Biosci. Bioeng. 2000, 89, 515-521. [CrossRef]

77. Alabouvette, C.; Olivain, C.; Steinberg, C. Biological control of plant diseases. Eur. J. Plant Pathol. 2006, 114, 329-341. [CrossRef]

78. Van Loon, L. Plant responses to plant growth-promoting rhizobacteria. Eur. J. Plant Pathol. 2007, 119, $243-254$. [CrossRef]

79. Smith, S.E.; Read, D.J. Mycorrhizal Symbiosis, 3rd ed.; Academic Press: London, UK, 2008. [CrossRef]

80. Manchanda, G.; Garg, N. Endomycorrhizal and rhizobial symbiosis: How much do they share? J. Plant Interact. 2007, 2, 79-88. [CrossRef]

81. Paul, E.A. Soil Microbiology and Biochemistry, 4th ed.; Academic Press: Cambridge, MA, USA; Elsevier: Amsterdam, The Netherlands, 2015; p. 598. [CrossRef]

82. Linderman, R.G. Mycorrhizal interactions in the rhizosphere. In The Rhizosphere and Plant Growth. Beltsville Symposia in Agricultural Research; Keister, D.L., Cregan, P.B., Eds.; Springer: Dordrecht, The Netherlands, 1991; Volume 14, pp. 343-348. [CrossRef] 
83. Basu, S.; Rabara, R.C.; Negi, S. AMF: The future prospect for sustainable agriculture. Physiol. Mol. Plant Pathol. 2018, 102, 36-45. [CrossRef]

84. Hawkins, H.J.; Johansen, A.; George, E. Uptake and transport of organic and inorganic nitrogen by arbuscular mycorrhizal fungi. Plant Soil 2000, 226, 275-285. [CrossRef]

85. Marschner, H.; Dell, B. Nutrient uptake in mycorrhizal symbiosis. In Management of Mycorrhizas in Agriculture, Horticulture and Forestry; Robson, A.D., Abott, L.K., Malaccjuk, N., Eds.; Plant Soil; Kluwer Academic Publishers: Amsterdam, The Netherlands, 1994; Volume 159, pp. 89-102. [CrossRef]

86. Morrison, E.N.; Emery, R.J.N.; Saville, B.J. Phytohormone Involvement in the Ustilago maydis-Zea mays Pathosystem: Relationships between abscisic acid and cytokinin levels and strain virulence in infected cob tissue. PLoS ONE 2015, 10, e0130945. [CrossRef] [PubMed]

87. Tahat, M.M.; Kamaruzaman, S.; Othman, R. Mycorrhizal fungi as a biocontrol agent. Plant Pathol. J. 2010, 9, 198-207. [CrossRef]

88. Panwar, J.; Yadav, R.S.; Yadav, B.K.; Tarafdar, J.C. Arbuscular Mycorrhizae: A dynamic micro-symbiont for sustainable agriculture: In Mycorrhizae: Sustainable Agriculture and Forestry; Springer: Dordrecht, The Netherlands, 2008; Volume 15, pp. 9-176. [CrossRef]

89. Heidari, M.; Karami, V. Effects of different mycorrhiza species on grain yield, nutrient uptake and oil content of sunflower under water stress. J. Saudi Soc. Agric. Sci. 2014, 13, 9-13. [CrossRef]

90. Mobasser, H.R.; Moradgholi, A.; Mehraban, A.; Koohkan, S. Investigation of mycorrhizal effect on agronomic traits and protein percent of corn varieties in Sistan. Int. J. Agric. Sci. 2012, 2, 108-119.

91. Prasanna, R.; Jaiswal, P.; Nayak, S.; Sood, A.; Kaushik, B.D. Cyanobacterial diversity in the rhizosphere of rice and its ecological significance. Indian J. Microbiol. 2009, 49, 89-97. [CrossRef]

92. Zulpa, G.; Zaccaro, M.C.; Boccazzi, F.; Parada, J.L.; Storni, M. Bioactivity of intra and extracellular substances from cyanobacteria and lactic acid bacteria on "wood blue stain" fungi. Biol. Control 2003, 27, 345-348. [CrossRef]

93. Yuen, G.Y.; Craig, L.M.; Kerr, E.D.; Steadman, J.R. Influences of antagonist population levels, blossom development stage and canopy temperature on the inhibition of the Sclerotinia sclerotiorum on dry edible bean by Erwinia herbicola. Phytopathology 1994, 84, 495-501. [CrossRef]

94. El-Sheekh, M.M.; El-Shouny, W.A.; Osman, M.E.; El-gammal, E.W. Growth and heavy metals removal efficiency of Nostoc muscorum and Anabaena subcylindrica in sewage and industrial wastewater effluents. Environ. Toxicol. Pharmacol. 2005, 19, 357-365. [CrossRef]

95. El-Enany, A.E.; Issa, A.A. Cyanobacteria as a biosorbent of heavy metals in sewage water. Environ. Toxicol. Pharmacol. 2000, 8, 95-101. [CrossRef]

96. Dominic, T.; Madhusoodanan, P. Cyanobacteria from extreme acidic environments. Curr. Sci. 1999, 77, 1021-1023.

97. Belnap, J.; Lange, O. Biological soil crusts: Structure, function, and management. Ecol. Stud. $2001,150$. [CrossRef]

98. Perez, R.; Forchhammer, K.; Salerno, G.; Maldener, I. Clear differences in metabolic and morphological adaptations of akinetes of two Nostocales living in different habitats. Microbiology 2016, 162, $214-223$. [CrossRef]

99. Kultschar, B.; Llewellyn, C. Secondary metabolites in cyanobacteria. In Secondary Metabolites-Sources and Applications; InTech: London, UK, 2018; Volume 2, pp. 23-36.

100. Nisha, R.; Kaushik, A.; Kaushik, C.P. Effect of indigenous cyanobacterial application on structural stability and productivity of an organically poor semi-arid soil. Geoderma 2007, 138, 49-56. [CrossRef]

101. Kaushik, S.; Sahu, B.K.; Lawania, R.K.; Tiwari, R.K. Occurrence of heavy metals in lentic water of Gwalior region. Pollut. Res. 1999, 18, 137-140.

102. Singh, J.S. Cyanobacteria: A vital bio-agent in eco-restoration of degraded lands and sustainable agriculture. Clim. Chang. Environ. Sustain. 2014, 2, 133-137.

103. Acea, M.J.; Prieto Fernandez, A.; Diz Cid, N. Cyanobacterial inoculation of heated soils: Effect on microorganisms of $\mathrm{C}$ and $\mathrm{N}$ cycles and on chemical composition in soil surface. Soil Biol. Biochem. 2003, 35, 513-524. [CrossRef]

104. DeCaire, G.Z.; DeCano, M.S.; DeMule, M.C.; Palma, R.M.; Colombo, K. Exopolysaccharide of Nostoc muscorum (cyanobacteria) in the aggregation of soil particles. J. Appl. Phycol. 1997, 4, 249-253. [CrossRef] 
105. Tassara, C.; Zaccaro, M.C.; Storni, M.M.; Palma, M.; Zulpa, G. Biological control of lettuce white mold with cyanobacteria. Int. J. Agric. Biol. 2008, 10, 487-492.

106. Moura, G.S.; Franzener, G. Biodiversity of nematodes biological indicators of soil quality in the agroecosystems. Arq. Inst. Biol. 2017, 84, 1-8. [CrossRef]

107. Ritz, K.; Trudgill, D. Utility of nematode community analysis as an integrated measure of the functional state of soils: Perspectives and challenges. Plant Soil 1999, 212,1-11. [CrossRef]

108. Stone, D.; Costa, D.; Daniell, T.; Mitchell, S.; Topp, C.; Griffiths, B. Using nematode communities to test a European scale soil biological monitoring programme for policy development. Appl. Soil Ecol. 2016, 97, 78-85. [CrossRef]

109. Lambert, K.; Bekal, S. Introduction to plant-parasitic nematodes. Plant Health Instr. 2002, 10, $1094-1218$. [CrossRef]

110. Mekonen, S.; Petros, I.; Hailemariam, M. The role of nematodes in the processes of soil ecology and their use as bio-indicators. Agric. Biol. J. N. Am. 2017, 8, 132-140.

111. Neher, D.A. Ecology of plant and free-living nematodes in natural and agricultural soil. Annu. Rev. Phytopathol. 2010, 48, 371-394. [CrossRef] [PubMed]

112. Sánchez-Moreno, S.; Nicola, N.L.; Ferris, H.; Zalom, F.G. Effects of agricultural management on nematode-mite assemblages: Soil food web indices as predictors of mite community composition. Appl. Soil Ecol. 2009, 41, 107-117. [CrossRef]

113. Johan, H.; Leveau, J.; Gail, M.P. Bacterial mycophagy: Definition and diagnosis of a unique bacterial-fungal interaction. New Phytol. 2008, 177, 859-876. [CrossRef]

114. Khan, Z.; Kim, Y.H. A review on the role of predatory soil nematodes in the biological control of plant parasitic nematodes. Appl. Soil Ecol. 2007, 35, 370-379. [CrossRef]

115. Chen, J.; Ferris, H. The effects of nematode grazing on nitrogen mineralization during fungal decomposition of organic matter. Soil Biol. Biochem. 1999, 3, 1265-1279. [CrossRef]

116. Quist, C.W.; Gort, G.; Mulder, C.; Wilbers, R.H.P.; Termorshuizen, A.J.; Bakker, J.; Helder, J. Feeding preference as a main determinant of microscale patchiness among terrestrial nematodes. Mol. Ecol. Resour. 2017, 17, 1257-1270. [CrossRef]

117. Ferris, H. Contribution of nematodes to the structure and function of the soil food web. J. Nematol. 2010, 42, 63-67. [PubMed]

118. Neher, D.A. Role of nematodes in soil health and their use as indicators. J. Nematol. 2001, 33, 161-168.

119. Susilo, F.X.; Neutel, A.M.; van Noordwijk, M.; Hairiah, K.; Brown, G.; Swift, M.J. Soil biodiversity and food webs. In Below-Ground Interactions in Tropical Agroecosystems: Concepts and Models with Multiple Plant Components; Van Noordwijk, M., Cadisch, G., Ong, C.K., Eds.; CABI, International: Wallingford, UK, 2004; pp. 285-307. [CrossRef]

120. Koike, S.; Subbarao, K.; Davis, R.M.; Turini, A.T. Vegetable Diseases Caused by Soilborne Pathogens; UCANR Publications University of California: Oakland, CA, USA, 2003; Available online: https://anrcatalog.ucanr. edu/pdf/8099.pdf (accessed on 7 July 2019).

121. Astrom, B.; Gerhardson, B. Differential reactions of wheat and pea genotypes to root inoculation with growth-affecting rhizosphere bacteria. Plant Soil 1998, 109, 263-269. [CrossRef]

122. Stirling, G.; Hayden, H.; Pattison, T.; Stirling, M. Soil health, soil biology, soilborne diseases and sustainable agriculture: A guide. Australas. Plant Pathol. 2017, 46, 387. [CrossRef]

123. Ellouze, W.; Esmaeili Taheri, A.; Bainard, L.D.; Yang, C.; Bazghaleh, N.; Navarro-Borrell, A.; Hanson, K.; Hamel, C. Soil fungal resources in annual cropping systems and their potential for management. Biomed. Res. Int. 2014, 53, 18-24. [CrossRef]

124. Larkin, R.P.; Honeycutt, C.W.; Olanya, O.M.; Halloran, J.M.; He, Z. Impacts of crop rotation and irrigation on soilborne diseases and soil microbial communities. In Sustainable Potato Production: Global Case Studies; He, Z., Larkin, R., Honeycutt, W., Eds.; Springer: Dordrecht, The Netherlands, 2012. [CrossRef]

125. Goreta Ban, S.; Zanic, K.; Dumiciv, G.; Raspudic, E.; Selak, G.; Ban, D. Growth and yield of grafted cucumbers in soil infested with root-knot nematodes. Chil. J. Agric. Res. 2014, 74, 29-34. [CrossRef]

126. Govaerts, B.; Fuentes, M.; Mezzalama, M.; Nicol, J.M.; Deckers, J.; Etchevers, J.D.; Figueroa-Sandoval, B.; Sayre, K.D. Infiltration, soil moisture, root rot and nematode populations after 12 years of different tillage, residue and crop rotation managements. Soil Tillage Res. 2007, 94, 209-219. [CrossRef] 
127. Dong, K.; Dong, Y.; Zheng, L.; Tang, Z.; Yang, X. Faba bean fusarium wilt (Fusarium oxysporum) control and its mechanism in different wheat varieties and faba bean intercropping system. Chin. J. Appl. Ecol. 2014, 25, 1979-1987.

128. Gutierrez, W.A.; Shew, H.D.; Melton, T.A. Sources of inoculum and management for Rhizoctonia solani damping-off on tobacco transplants under greenhouse conditions. Plant Dis. 1997, 81, 604-606. [CrossRef]

129. Xiao, C.L.; Subbarao, K.V.; Schulback, K.F.; Koike, S.T. Effects of crop rotation and irrigation on Verticillium dahliae microsclerotia in soil and wilt in cauliflower. Phytopathology 1998, 88, 1046-1055. [CrossRef]

130. Ristaino, J.B.; Perry, K.B.; Lumsden, R.D. Effect of solarization and Gilocladium virens on sclerotia of Sclerotium folfsii, soil microbiota and the incidence of southern blight of tomato. Phytopathology 1991, 81, 1117-1124. [CrossRef]

131. Sid, A.; Pérez, S.C.; Egea, G.C.; Candela, M.E. Evaluation of the capacity of Trichoderma harzianum in controlling rot caused by Phytophthora capsici in pepper plants. Plant Pathol. 1999, 48, 58-65. [CrossRef]

132. Tanović, B.; Potočnik, I.; Delibašic, G.; Ristić, M.; Kostić, M.; Marković, M. In vitro effect of essential oils from aromatic and medicinal plants on mushroom pathogens: Verticillium fungicola var. fungicola, Mycogone perniciosa, and Cladobotryum sp. Arch. Biol. Sci. 2009, 61, 231-237.

133. Taiwo, L.B.; Adebayo, D.T.; Adebayo, O.S.; Adediran, J.A. Compost and Glomus mosseae for management of bacterial and Fusarium wilts of tomato. Int. J. Veg. Sci. 2007, 13, 49-61. [CrossRef]

134. Norman, D.J.; Chen, J.; Yuen, J.M.F.; Mangravita-Novo, A.; Byrne, D.; Walsh, L. Control of bacterial wilt of geranium with phosphorous acid. Plant Dis. 2006, 90, 798-802. [CrossRef]

135. Fernandes, V.C.; Domingues, V.F.; de Freitas, V.; Delerue-Matos, C.; Mateus, N. Strawberries from integrated pest management and organic farming: Phenolic composition and antioxidant properties. Food Chem. 2012, 134, 1926-1931. [CrossRef]

136. Gong, W.; Yan, X.; Wang, J.; Hu, T.; Gong, Y. Long-term application of chemical and organic fertilizers on plant-available nitrogen pools and nitrogen management index. Biol. Fertil. Soils 2011, 47, 767-775. [CrossRef]

137. Mäder, P.; Fließbach, A.; Dubois, D.; Gunst, L.; Fried, P.; Niggli, U. Soil fertility and biodiversity in organic farming. Science 2002, 296, 1694-1697. [CrossRef]

138. Schrama, M.; de Haan, J.; Kroonen, M.; Verstegen, H.; Van der Putten, W. Crop yield gap and stability in organic and conventional farming systems. Agric. Ecosyst. Environ. 2018, 256, 123-130. [CrossRef]

139. Organic Production/Organic Food: Information Access Tools. USDA. Available online: https://www.nal. usda.gov/afsic/organic-productionorganic-food-information-access-tools (accessed on 8 June 2020).

140. Matoh, T.; Saraswati, R.; Phupaibul, P.; Sekiya, J. Growth characteristics of Sesbania species under adverse edaphic conditions in relation to use as green manure in Japan. J. Soil Sci. Plant Nutr. 1992, 38, 741-747. [CrossRef]

141. Chang, E.; Wang, C.; Chen, C.; Chung, R. Effects of long-term treatments of different organic fertilizers complemented with chemical $\mathrm{N}$ fertilizer on the chemical and biological properties of soils. J. Soil Sci. Plant Nutr. 2014, 60, 499-511. [CrossRef]

142. Chou, Y.; Shen, F.; Chiang, S.; Chang, C. Functional diversity and dominant populations of bacteria in banana plantation soils as influenced by long-term organic and conventional farming. Appl. Soil Ecol. 2017, 110, 21-33. [CrossRef]

143. Iovieno, P.; Morra, L.; Leone, A.; Pagano, L.; Alfani, A. Effect of organic and mineral fertilizers on soil respiration and enzyme activities of two Mediterranean horticultural soils. Biol. Fertil. Soils 2009, 45, 555-561. [CrossRef]

144. Qiu, M.; Zhang, R.; Xue, C.; Zhang, S.; Li, S.; Zhang, N.; Shen, Q. Application of bio-organic fertilizer can control Fusarium wilt of cucumber plants by regulating microbial community of rhizosphere soil. Biol. Fertil. Soils 2012, 48, 807-816. [CrossRef]

145. Atandi, J.G.; Haukeland, S.; Kariuki, G.M.; Coyne, D.L.; Karanja, E.N.; Musyoka, M.W.; Fiaboe, K.K.; Bautze, D.; Adamtey, N. Organic farming provides improved management of plant parasitic nematodes in maize and bean cropping systems. Agric. Ecosyst. Environ. 2017, 247, 265-272. [CrossRef]

146. Chang, E.; Chung, R.; Wang, F. Effect of different types of organic fertilizers on the chemical properties and enzymatic activities of an Oxisol under intensive cultivation of vegetables for 4 years. J. Soil Sci. Plant Nutr. 2008, 54, 587-599. [CrossRef] 
147. Othman, Y.; Leskovar, D. Organic soil amendments influence soil health, yield, and phytochemicals of globe artichoke heads. Biol. Agric. Hortic. 2018, 34, 258-267. [CrossRef]

148. Mangalasserya, S.; Kalaivananb, D.; Philipc, P. Effect of inorganic fertilisers and organic amendments on soil aggregation and biochemical characteristics in a weathered tropical soil. Soil Tillage Res. 2019, 187, 144-151. [CrossRef]

149. Fischer, R.A. Definitions and determination of crop yield, yield gaps, and of rates of change. Field Crops Res. 2015, 182, 9-18. [CrossRef]

150. De Ponti, T.; Rijk, B.; van Ittersum, M. The crop yield gap between organic and conventional agriculture. Agric. Syst. 2012, 108, 1-9. [CrossRef]

151. Bassouny, M.; Chen, J. Effect of long-term organic and mineral fertilizer on physical properties in root zone of a clayey Ultisol. Arch. Agron. Soil Sci. 2016, 62, 819-828. [CrossRef]

152. Escanhoela, A.S.; Pitombo, L.M.; Brandani, C.B.; Navarrete, A.A.; Bento, C.B.; Carmo, J.B. Organic management increases soil nitrogen but not carbon content in a tropical citrus orchard with pronounced $\mathrm{N}_{2} \mathrm{O}$ emissions. J. Environ. Manag. 2019, 234, 326-335. [CrossRef]

153. Suja, G.; Byju, G.; Jyothi, A.N.; Veena, S.S.; Sreekumar, J. Yield, quality and soil health under organic vs conventional farming in taro. Sci. Hortic. 2017, 218, 334-343. [CrossRef]

154. Maqueda, C.; Herencia, J.F.; Ruiz, J.C.; Hidalgo, M.F. Organic and inorganic fertilization effects on DTPA-extractable $\mathrm{Fe}, \mathrm{Cu}, \mathrm{Mn}$ and $\mathrm{Zn}$, and their concentration in the edible portion of crops. J. Agric. Sci. 2011, 149, 461-472. [CrossRef]

155. Gaskell, M.; Smith, R. Nitrogen sources for organic vegetable crops. HortTechnology 2007, 17, $431-441$. [CrossRef]

156. Mikkelsen, R.; Hartz, T. Nitrogen sources for organic crop production. Better Crops 2008, 92, 16-19.

157. Zhao, W.; Yang, X.; Yu, H.; Jiang, W.; Sun, N.; Liu, X.; Liu, X.; Zhang, X.; Wang, Y.; Gu, X. RNA-Seq-based transcriptome profiling of early nitrogen deficiency response in cucumber seedlings provides new insight into the putative nitrogen regulatory network. Plant Cell Physiol. 2015, 56, 455-467. [CrossRef] [PubMed]

158. Antonious, G.; Turley, E.; Snyder, J. Chicken manure enhanced yield and quality of field-grown kale and collard greens. J. Environ. Sci. Health B 2014, 49, 299-304. [CrossRef]

159. Woese, K.; Lange, D.; Boess, C.; Bögl, K. A comparison of organically and conventionally grown foods-results of a review of the relevant literature. J. Sci. Food Agric. 1997, 74, 281-293. [CrossRef]

160. Worthington, V. Nutritional quality of organic versus conventional fruits, vegetables, and grains. J. Altern. Complement. Med. 2001, 7, 161-173. [CrossRef]

161. Fernandez-Salvador, J.; Strik, B. Liquid corn and fish fertilizers are good options for fertigation in blackberry cultivars grown in an organic production system. Hortic. Sci. 2015, 50, 225-233. [CrossRef]

162. Vyn, T.; Faber, J.; Janovicek, K.; Beauchamp, E. Cover crop effects on nitrogen availability to corn following wheat. Agron. J. 2000, 92, 915-924. [CrossRef]

163. Fauci, M.F.; Dick, R.P. Plant response to organic amendments and decreasing inorganic nitrogen rates in soils from long-term experiment. Soil Sci. Soc. Am. J. 1994, 58, 134-138. [CrossRef]

164. Fageria, N. Green manuring in crop production. J. Plant Nutr. 2007, 30, 691-719. [CrossRef]

165. Gathala, M.K.; Timsina, J.; Islam, M.S.; Rahman, M.M.; Hossain, M.I.; Harun-Ar-Rashid, M.; Ghosh, A.K.; Krupnik, T.J.; Tiwari, T.P.; McDonald, A. Conservation agriculture based tillage and crop establishment options can maintain farmers' yields and increase profits in South Asia's rice-maize systems: Evidence from Bangladesh. Field Crops Res. 2015, 172, 85-98. [CrossRef]

166. Jabro, J.D.; Stevens, W.B.; Evans, R.G.; Iversen, W.M. Tillage effects on physical properties in two soils of the Northern Great Plains. Appl. Eng. Agric. 2009, 25, 377-382. [CrossRef]

167. Gozubuyuk, Z.; Sahin, U.; Ozturk, I.; Celik, A.; Adiguzel, M.C. Tillage effects on certain physical and hydraulic properties of a loamy soil under a crop rotation in a semi-arid region with a cool climate. CATENA 2014, 118, 195-205. [CrossRef]

168. Cannell, R.; Hawes, J. Trends in tillage practices in relation to sustainable crop production with special reference to temperate climates. Field Crops Res. 1994, 30, 245-282. [CrossRef]

169. Jat, M.L.; Gathala, M.K.; Saharawat, Y.S.; Tetarwal, J.P.; Gupta, R. Double no-till and permanent raised beds in maize-wheat rotation of North-Western Indo-Gangetic Plains of India: Effects on crop yields, water productivity, profitability and soil physical properties. Field Crops Res. 2013, 149, 291-299. [CrossRef] 
170. Al-Kaisi, M.; Douelle, A.; Kwaw-Mensah, D. Soil microaggregate and macroaggregate decay over time and soil carbon change as influenced by different tillage systems. J. Soil Water Conserv. 2014, 69, 574-580. [CrossRef]

171. Shao, Y.; Xie, Y.; Wang, C.; Yue, J.; Yao, Y.; Liu, W. Effects of different soil conservation tillage approaches on soil nutrients, water use and wheat-maize yield in rainfed dry-land regions of North China. Eur. J. Agron. 2016, 81, 37-45. [CrossRef]

172. Celik, A.; Altikat, S.; Way, T. Strip tillage width effects on sunflower seed emergence and yield. Soil Tillage Res. 2013, 131, 20-27. [CrossRef]

173. Mullins, G.L.; Alley, S.E.; Reeves, D.W. Tropical maize response to nitrogen and starter fertilizer under strip and conventional tillage systems in southern Alabama. Soil Tillage Res. 1998, 45, 1-15. [CrossRef]

174. Jat, M.L.; Gathala, M.K.; Ladha, J.K.; Saharawat, Y.S.; Jat, A.S.; Vipin, K.; Sharma, S.K.; Kumar, V.; Gupta, R.K. Evaluation of precision land leveling and double zero-till systems in the rice-wheat rotation: Water use, productivity, profitability and soil physical properties. Soil Tillage Res. 2009, 105, 112-121. [CrossRef]

175. Saharawat, Y.S.; Ladha, J.K.; Pathak, H.; Gathala, M.; Chaudhary, N.; Jat, M.L. Simulation of resource-conserving technologies on productivity, income and greenhouse gas (GHG) emission in rice-wheat system. J. Soil Sci. Environ. 2012, 3, 9-22.

176. Vivak, K.; Saharawat, Y.S.; Gathala, M.K.; Jat, A.S.; Singh, S.K.; Chaudhary, N.; Jat, M.L. Effect of different tillage and seeding methods on energy use efficiency and productivity of wheat in Indo-Gangetic plains. Field Crops Res. 2013, 142, 1-8. [CrossRef]

177. Bhushan, L.; Ladha, J.K.; Gupta, R.K.; Singh, S.; Tirol-Padre, A.; Saharawat, Y.S.; Gathala, M.; Pathak, H. Saving of water and labor in a rice-wheat system with no-tillage and direct seeding technologies. Agron. J. 2008, 99, 1288-1296. [CrossRef]

178. Mohammad, W.; Shah, S.M.; Shehzadi, S.; Shah, S.A. Effect of tillage, rotation and crop residues on wheat crop productivity: Fertilizer nitrogen and water use efficiency and soil organic carbon status in dry area (rainfed) of north-west Pakistan. J. Soil Sci. Plant Nutr. 2012, 12, 715-727. [CrossRef]

179. Zhang, Y.J.; Wang, S.; Wang, H.; Ning, F.; Zhang, Y.; Dong, Z.; Wen, P.; Wang, R.; Wang, X.; Jun, L. The effects of rotating conservation tillage with conventional tillage on soil properties and grain yields in winter wheat-spring maize rotations. Agric. For. Meteorol. 2018, 263, 107-117. [CrossRef]

180. Sengupta, A.; Dick, W. Bacterial community diversity in soil under two tillage practices as determined by pyrosequencing. Microb. Ecol. 2015, 70, 853-859. [CrossRef]

181. Yang, S.; Kim, M.; Seo, Y.; Choi, K.; Lee, S.; Kwak, Y.; Lee, Y. Soil microbial community analysis of between no-till and tillage in a controlled horticultural field. World J. Microbiol. Biotechnol. 2012, 28, 1797-1801. [CrossRef] [PubMed]

182. Overstreet, L.; Hoyt, G.; Imbriani, J. Comparing nematode and earthworm communities under combinations of conventional and conservation vegetable production practices. Soil Tillage Res. 2010, 110, 42-50. [CrossRef]

183. Sharratt, B.; Zhang, M.; Sparrow, S. Twenty years of conservation tillage research in subarctic Alaska II. Impact on soil hydraulic properties. Soil Tillage Res. 2006, 91, 82-88. [CrossRef]

184. Hobbs, P.R. Conservation agriculture: What is it and why is it important for future sustainable food production? J. Agric. Sci. 2007, 145, 127-138. [CrossRef]

185. Ito, T.; Araki, M.; Komatsuzaki, M.; Kaneko, N.; Ohta, H. Soil nematode community structure affected by tillage systems and cover crop managements in organic soybean production. Appl. Soil Ecol. 2015, 86, 137-147. [CrossRef]

186. Melman, D.; Kelly, C.; Schneekloth, J.; Calderón, F.; Fonte, S. Tillage and residue management drive rapid changes in soil macrofauna communities and soil properties in a semiarid cropping system of Eastern Colorado. Appl. Soil Ecol. 2019, 143, 98-106. [CrossRef]

187. Johnson-Maynard, J.L.; Umiker, K.J.; Guy, S.O. Earthworm dynamics and soil physical properties in the first three years of no-till management. Soil Tillage Res. 2007, 94, 338-345. [CrossRef]

188. Van Schaik, L.; Palm, J.; Klaus, J.; Zehe, E.; Schröder, B. Potential effects of tillage and field borders on within-field spatial distribution patterns of earthworms. Agric. Ecosyst. Environ. 2016, 228, 82-90. [CrossRef]

(C) 2020 by the authors. Licensee MDPI, Basel, Switzerland. This article is an open access article distributed under the terms and conditions of the Creative Commons Attribution (CC BY) license (http://creativecommons.org/licenses/by/4.0/). 